\title{
Articles
}

\section{Policing the Cease-and-Desist Letter}

\author{
By LEAH CHAN GRINVALD*
}

\section{Introduction}

The U.S. RePUtation FOR LITIGIOUSNESS is so pervasive that it has entered our cultural fabric: books and articles have been written about it and a variety of popular media have satirized our infamy. ${ }^{1}$ There is a paradox, though. Statistics show that approximately only three percent of all legal disputes are brought to the judicial system. ${ }^{2}$ Of this three percent, only a small fraction of disputes are litigated to a final decision. ${ }^{3}$ How can

* C) 2015 Leah Chan Grinvald. Associate Professor of Law, Suffolk University Law School. B.A., The George Washington University; J.D., NYU School of Law. For their helpful comments and conversations regarding this Article, the Author would like to thank Gaia Bernstein, Christian Czychowski, Stacey Dogan, Pamela Edwards, Yan Fang, William Gallagher, Jeffrey M. Gitchel, Paul Gugliuzza, Michael Meurer, Andrew Perlman, Lisa P. Ramsey, Sandra L. Rierson, Jessica Silbey, and Alan White. The Author would also like to thank all the participants at the various presentations of this Article: INTA's 2015 Academic Day Scholarship Symposium, Boston University School of Law's IP Law Speakers' Series, the 14th Annual Intellectual Property Scholars Conference, the CUNY Law Faculty Workshop, and the 2013 New England Junior Scholars' Workshop. Finally, the Author would like to thank Dahlia Ali and Jordan Marciello for their excellent research assistance, Suffolk University School of Law for their financial support, and the editors of the University of San Francisco Law Review. Feedback is most welcome: Lgrinvald@suffolk.edu.

1. See, e.g., Seinfeld: The Maestro (NBC television broadcast Oct. 5, 1995) (satirizing Liebeck v. McDonald's Rests., P.T.S., Inc., No. CV-93-02419, 1995 WL 360309 (D.N.M. Aug. 18, 1994), vacated, 1994 WL 16777704 (D.N.M. Nov. 28, 1994)). In this episode of Seinfeld, one of the main characters, Kramer, sues a local coffee shop for serving him coffee that was "too hot," burning his stomach (because he had attempted to sneak the coffee hidden in his waistband into a movie theater). Id.

2. See William M. Landes, An Empirical Analysis of Intellectual Property Litigation: Some Preliminary Results, 41 Hous. L. REV. 749, 761 (2004).

3. See Kenneth L. Port, Trademark Extortion: The End of Trademark Law, 65 WASH. \& LEE L. ReV. 585, 589 (2008); Megan M. La Belle, Against Settlement of (Some) Patent Cases, 67 VAND. L. ReV. 375,377 (2014). 
Americans still be so litigious while simultaneously having fairly low per capita rates of lawsuits? 4 This Article suggests that the growing practice of resolving disputes through the use of abusive cease-and-desist letters is the answer to this paradox. 5 Cease-and-desist letters are abusive when they contain a threat (implicit or explicit) of litigation if the target does not comply with the letter's demands, as well as one or more of the following items: unnecessary legalese (including unsubstantiated statutory citations), demands for a settlement within a short time frame, demands for immediate payment of some form of fees, and/or weak legal claims. ${ }^{6}$ Based on this growing trend and the potential harms these letters bring, this Article proposes that when abusive cease-and-desist letters are sent to vulnerable populations, such as small businesses or individuals, a certain amount of policing is needed.

While there are no comprehensive statistics documenting how many cease-and-desist letters are sent each year, there are strong indications of increasing frequency at least in the intellectual property field.7 For example, a recent qualitative empirical study evaluating experienced intellectual property attorneys found that almost all of the interviewed attorneys handled the majority of their clients' disputes through cease-and-desist letters. ${ }^{8}$ These

4. See Deborah L. Rhode, Frivolous Litigation and Civil Fustice Reform: Miscasting the Problem, Recasting the Solution, 54 DUKE L.J. 447, 456 (2004) (stating that current litigation rates in the United States are not exceptionally high). The per capita rate of litigation in the United States is similar to that of peer nations, such as England and Australia. Id.; see also Herbert M. Kritzer, Laweyer Fees and Lawerer Behavior in Litigation: What Does the Empirical Literature Really Say?, 80 TEX. L. REV. 1943, 1981-82 (2002).

5. See, e.g., Eriq Gardener, How to Write an Effectively Nasty Lawyer Letter, HOLLYWOOD REP. (July 18, 2012), http://www.hollywoodreporter.com/thr-esq/marty-singer-cease-and-desist-letter350612 ("In the cutthroat world of Hollywood law, the pen can be mightier than the sword. With litigation costs skyrocketing and court dockets clogged, a forceful cease-and-desist letter is increasingly a much quicker and more effective weapon than the sharp blade of litigation. But it is not without risks.").

6. See, e.g., Letter from Diane M. Reed, Attorney, Knobbe Martens Olson \& Bear LLP, to Christopher J. Day, Law Office of Christopher Day (Sept. 4, 2009) (on file with author) (requiring compliance with the listed demands within two weeks from date of letter); Letter from Nat'l Football League to Ms. Thom, Fleurty Girl (Jan. 13, 2010) (on file with author) (requiring compliance with the listed demands within nine days from date of letter).

7. See Irina D. Manta, Bearing Down on Trademark Bullies, 22 Fordham Intell. Prop. MEDIA \& ENT. L.J. 853, 854-57 (2012) (discussing the rise in trademark bullying through the sending of cease-and-desist letters); Marketa Trimble, Setting Foot on Enemy Ground: Cease-and-Desist Letters, DMCA Notifications and Personal Furisdiction in Declaratory Fudgment Actions, 50 IDEA 777, 784 (2010) ("[C]ease-and-desist letters are frequently utilized in disputes concerning intellectual property and represent an important feature of the intellectual property law landscape.").

8. William T. Gallagher, Trademark and Copyright Enforcement in the Shadow of IP Law, 28 SANTA Glara Computer \& High Tech. L.J. 453, 481-82 (2012) (describing the phenomenon as "demand letter lawyering"). 
same lawyers admitted that where such letters are sent to small businesses or individuals, it was often more effective to be "abusive."9 While the study participants do not use the term "abusive," the manner in which they enforce rights against low-resourced entities, such as small businesses and individuals, can be deemed abusive under this Article's definition. 10 In addition, these lawyers also admitted that they tended to enforce claims through cease-anddesist letters, even where the lawyers believed the claims had little merit.11 Further, the fact that state government and legislative entities believe there is a current need to address the issue of "patent trolls,"12 provides support for this growing trend. 13

Although there are a variety of influences spurring the increased use of abusive cease-and-desist letters, four likely culprits are (1) the exorbitant cost of litigation and its outcome uncertainty, (2) the lack of legal consequences for sending such letters, and (3) the effectiveness of the letters. Litigation is expensive, and therefore, it is in the intellectual property rights holders' best economic interest (even for multinational corporations with large legal budgets) to try to and resolve disputes without resorting to litigation. ${ }^{14}$ Additionally, in certain areas of the law (in particular, in intellectual property law), the outcome of litigation is not easily predicted due to the uncertainties

\footnotetext{
9. See id. at 478 .

10. See id.; see also infra Part I.B (discussing four factors that create an abusive cease-and-desist letter).

11. Gallagher, supra note 8 , at 475,481 (stating that one of the themes of the study was the extent to which the participants enforced weak claims).

12. "Patent trolls" are typically defined as business entities that have obtained patent rights for the sole purpose of obtaining licensing fees through coercion (such as threats of litigation). See

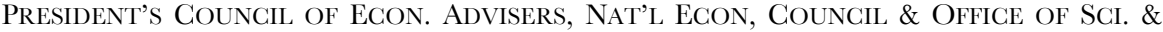
Tech. Policy, Executive Office of the President, Patent Assertion AND INNOVATION 3-4 (2013) [hereinafter WHITE HOUSE REPORT]. The specific problems related to patent trolls have been extensively explored in academic literature and have also been highlighted as an executive-level policy concern to the U.S. economy. See id. at 12-13; James Bessen, Jennifer Ford \& Michael J. Meurer, The Private and Social Costs of Patent Trolls 2 (Bos. Univ. Sch. of Law, Working Paper No. 11-45, 2011), available at http://www.bu.edu/law/faculty/scholarship /workingpapers/documents/Bessen-Ford-Meurer-no-11-45rev.pdf ("We find that NPE lawsuits are associated with half a trillion dollars of lost wealth to defendants from 1990 through 2010 ...”). See also infra Part III.C.

13. See, e.g., Press Release, N.Y. Att'y Gen. Office, A.G. Schneiderman Announces Groundbreaking Settlement with Abusive "Patent Troll" (Jan. 14, 2014), http://ag.ny.gov/pressrelease/ag-schneiderman-announces-groundbreaking-settlement-abusive- $\% \mathrm{E} 2 \% 80 \% 9 \mathrm{Cp}$ patenttroll $\% \mathrm{E} 2 \% 80 \% 9 \mathrm{D}$ [hereinafter N.Y. Press Release].

14. See, e.g., Trimble, supra note 7, at 787 (citing Bruce Sewell, Intel's General Counsel, who estimates Intel's costs for dealing with patent infringement claims are around three to five million dollars per year).
} 
in the applicability of some doctrines and their corresponding defenses. 15 Furthermore, the patchwork of regulation and laws that could provide some deterrence for sending cease-and-desist letters is ineffective. Currently, the American Bar Association (ABA) Model Rules of Professional Conduct, 16 Federal Rules of Civil Procedure, newly enacted state laws, and consumer protection laws (as enforced by state attorneys general or the Federal Trade Commission (FTC)) have the potential to police abusive cease-and-desist letters. 17

However, this Article's review of these potential forms of regulation reveals severe limitations that allow abusive cease-and-desist letter senders to virtually evade any form of legal consequence. 18 Therefore, abusive letters remain effective because the same incentives that encourage rights holders to send abusive cease-and-desist letters disincentivize the targets to fight back. Moreover, when abusive cease-and-desist letters are sent to small businesses and individuals, it is almost certain that such targets will immediately capitulate.19 The effectiveness of such letters is due to a confluence of three factors that create a coercive settlement process - an abusive letter, asymmetrical disputants, and certain characteristics of small businesses and individuals. 20

This Article argues that more effective and coordinated tools are needed to police abusive cease-and-desist letters. Specifically, the approach needs to directly address the characteristics of small businesses and individuals in order to be successful. One such proposal is adopting federal or state legislation, similar to the recently passed state-level, anti-patent troll legislation, 21 but with a broader focus. This "anti-abusive threats" legislation

15. See Leah Chan Grinvald, Shaming Trademark Bullies, 2011 WIS. L. REV. 625, 657-61 (2011) (identifying three factors that lead to the unpredictability of trademark infringement lawsuits).

16. As enacted by individual states.

17. See infra Part III.

18. Id. One limitation includes the myopic focus on "patent trolls." See infra Part III.C.

19. See Gallagher, supra note 8, at 478 ("Q: Why go after the little guy? A: Ease. It's easy often. You can often get them to roll over with a few threats and some sweet talk. . . Threats means we'll sue your sorry little company if you don't stop."). See also William McGeveran, Four Free Speech Goals for Trademark Law, 18 FORDHAM INTELL. PROP. MEDIA \& ENT. L.J. 1205, 1206-07 (2008) (noting that cease-and-desist letters are frequently effective); William E. Ridgway, Revitalizing the Doctrine of Trademark Misuse, 21 BERKELEY TECH. L.J. 1547, 1569 (2006).

20. See Gallagher, supra note 8, at 478 .

21. See Patent Progress's Guide to State Patent Legislation, PATENT Progress, http://www.patentprogress.org/patent-progress-legislation-guides/patent-progresss-guide-statepatent-legislation/ (last updated Apr. 17, 2015) (providing an interactive map of states with different stages of anti-patent troll bills, showing that twenty-two states have signed legislation into law). 
would provide targeted parties with a cause of action against the sender of an abusive letter. The legislation would provide for a "fast-track" resolution of the abuse claim by a judge, as well as contain an attorneys' fee-shifting provision if the sender's letter was deemed abusive. 22 With the potential for recovering attorneys fees and fast-track resolution, more attorneys would be willing to represent small businesses and individuals on a contingency fee basis. ${ }^{23}$ Adequate representation would assist in overcoming this population's inability to information-gather, as well as its susceptibility to inducement.24 Since adopting legislation may not be immediately forthcoming, and since it does not combat all the characteristics of this vulnerable population, this Article proposes supplemental, holistic measures that could also assist. These proposals include greater involvement by state bar associations and the ABA through issuing a formal ethics opinion regarding the direct applicability of the Model Rules of Professional Conduct to abusive cease-and-desist letters. Additionally, this Article proposes that state attorneys general should more aggressively interpret their current consumer protection laws to allow them to take further action against senders of abusive cease-and-desist letters.

Part I provides an overview of the cease-and-desist letter process and defines this Article's use of the term "abusive cease-and-desist letter." Part II discusses the characteristics of small businesses and individuals that render them susceptible to these abusive letters. Part II also conducts an analysis of the incentives that rights holders have to send an abusive letter. Part II further examines the problems associated with sending abusive cease-anddesist letters, including philosophical concerns with coerced agreements. Part III examines existing mechanisms that could serve to police abusive ceaseand-desist letters, including the Model Rules of Professional Conduct and recently enacted state legislation, but ultimately concludes that such mechanisms do not effectively regulate this legal gray area.

In response, Part IV provides a number of proposals, including revised federal and/or state legislation aimed at curbing abusive cease-and-desist letters for all types of legal actions. Part $\mathrm{V}$ proactively addresses a number of concerns that may be raised in response to these proposals, including the

22. See infra Part IV.A.4.

23. See Grinvald, supra note 15, at 656-57 (citing small businesses and individuals' lack of monetary resources as a hurdle to accessing adequate legal resources for intellectual property disputes).

24. See Carrie Johnson, Rights Advocates See 'Access to Fustice' Gap in the U.S., NPR (Mar. 10, 2014), http://www.npr.org/blogs/thetwo-way/2014/03/10/288225649/rights-advocates-seeaccess-to-justice-gap-in-u-s (reporting on recent research conducted by Columbia Law School's Human Rights Clinic showing that individuals with access to counsel fare considerably better in civil legal disputes). 
concern that implementing new legislation to combat abusive cease-anddesist letters may encourage additional litigiousness by plaintiffs' attorneys. However, Part V provides suggestions to counter these concerns. This Article then briefly concludes that the problems in this area are serious enough to outweigh the concerns.

\section{The Cease-and-Desist Letter Process}

Private dispute resolution is not a new phenomenon. A number of empirical studies from the latter part of the twentieth century show that most disputes are negotiated privately, without recourse to the judicial system. 25 The current statistics of per capita civil litigation in the United States supports this conclusion: only three percent of all civil disputes proceed to litigation, 26 and of this number, approximately one percent progress to a judicially-determined result.27 Despite the actual statistics, the U.S. reputation for litigiousness maintains its resonance. 28 This Article asserts that one of the answers to the paradox of the U.S. reputation for litigiousness is the growing trend of settling disputes through cease-and-desist letters, and in particular, the use of abusive cease-and-desist letters to coerce a private settlement. 29

Although there are few statistics to prove this overall trend, Professor William Gallagher's empirical study of the enforcement of intellectual

25. See David M. Trubek, Joel B. Grossman, William L.F. Felstiner, Herbert M. Kritzer \& Austin SARAT, Givil Litigation Research Project: Final Report S-75-76 (University of Wisconsin Law School, 1983); Richard E. Miller \& Austin Sarat, Grievances, Claims, and Disputes: Assessing the Adversary Culture, 15 LAW \& SoG'Y REV. 525, 543 (1980-1981); Stewart Macaulay, Non-Contractual Relations in Business: A Preliminary Study, 28 AM. Soc. Rev. 55, 61-62 (1963).

26. See Landes, supra note 2, at 761.

27. This statistic only encompasses federal district court civil cases for the twelve month period ending September 30, 2013. See U.S. COURTS, JudiCial Business Of THE U.S. COURTS: ANNUAL REPORT OF THE DIRECTOR 2013 tbl. C-4, available at http://www.uscourts.gov/uscourts/Statistics/JudicialBusiness/2013/appendices/C04Sep13.pdf. But see Theodore Eisenberg \& Charlotte Lanvers, What is the Settlement Rate and Why Should We Care?, 6 J. EMP. LEGAL STUD. 111, 113 (2009) (suggesting a higher percentage goes to trial).

28. See supra note 1.

29. See infra Part III.C (providing "patent troll" cease-and-desist letters as an example of this growing trend). See also infra Part I.B (defining "abusive" cease-and-desist letters). Cf. J. Mark Ramseyer \& Eric B. Rasmusen, Comparative Litigation Rates 39-40 (Harvard John M. Olin Discussion Paper Series, Discussion Paper No. 681, 2010), available at http://www.law.harvard.edu/programs/olin_center/papers/pdf/Ramseyer_681.pdf (suggesting that America's reputation for litigiousness partly stems from the mishandling of securities class action and mass tort lawsuits). 
property rights by attorneys offers some support. 30 His qualitative study of fifty-eight experienced intellectual property lawyers found that almost all conducted their dispute resolution by using cease-and-desist letters, which typically resulted in a privately negotiated settlement. 31 In fact, only five of these seasoned attorneys had ever actually litigated more than three cases. 32 Additionally, more than one-third of the participants had never brought a trademark or copyright case to trial over the course of their careers. 33 Further, these participants admitted that where such letters are sent to small businesses or individuals, strategically it was often more effective to be "abusive." 34 One of the study's conclusions was that the study participants routinely enforced "weak" claims without any perceived ethical dilemma. 35

In addition, recent state governmental actions against "patent trolls" 36 that send abusive cease-and-desist letters to small businesses also provides evidence for the conclusion that abusive cease-and-desist letters have been on the rise.37 For example, the state attorneys general in New York, Minnesota, Nebraska, and Vermont, have all taken action against a notorious patent troll for sending abusive letters to small businesses within

30. See generally Gallagher, supra note 8. In addition, a counter-factual is also helpful as proof of the growing trend. See also Megan Garber, This Cease-and-Desist Letter Should be the Model for Every Cease-and-Desist Letter, THE ATLANTIC (July 23, 2012), http://www.theatlantic.com /technology/archive/2012/07/this-cease-and-desist-letter-should-be-the-model-for-every-ceaseand-desist-letter/260170/\#. It was speculated that this cease-and-desist letter will go down in history as the "most polite, encouraging and empathetic" letter ever to be sent, and was a viral Internet sensation. Debra Cassens Weiss, Fack Daniel's Cease-and-Desist Letter Goes Viral for Being Exceedingly Polite, A.B.A. J. (July 26, 2012), http://www.abajournal.com/news/article /jack_daniels_cease-and-desist_letter_goes_viral_for_being_exceeedingly_poli/.

31. Gallagher, supra note 8, at 465, 481-82.

32. Id. at 465. Professor Gallagher excluded Trademark Trial and Appeal Board (TTAB) trials from counting as litigation since such trials are not conducted in person. Id. at 465 n.52. The low number of surveyed attorneys having litigation experience could partially be due to the fact that some simply preferred a transactional practice - if cases did not settle, some would refer cases to a more seasoned litigator instead of handling it themselves. $I d$. at 465 n.53.

33. Id. at 465. The range of the survey participants' experience in intellectual property enforcement ranged from five to forty years. $I d$.

34. While the study participants do not use the term "abusive," the manner in which they enforce rights against low-resourced entities, such as small businesses and individuals can be deemed abusive under this Article's definition. See id. at 478; see also infra Part I.B.

35. See Gallagher, supra note 8, at 496.

36. See sources cited supra note 12.

37. These state-level governmental actions have been in the form of legislation for "bad faith assertions of patent infringement" and state attorneys general actions against certain patent trolls for sending abusive letters. See, e.g., 9 VT. STAT. ANN. tit. 9, § 4195 (West 2015); N.Y. Press Release, supra note 13. 
their states. 38

While Professor Gallagher's numbers are restricted to a small sample of intellectual property attorneys, and the governmental actions have been limited, there are enough anecdotes to support the conclusion that the rise of abusive cease-and-desist letters are not limited to the intellectual property field. 39 Unfortunately, abusive cease-and-desist letters are most problematic when the letters target low-resourced entities, such as small businesses and individuals.

\section{A. Overview of the Cease-and-Desist Letter Process}

The Internet has been one of the main drivers for the increased use of cease-and-desist letters in legal dispute resolution. Potential violations of one's rights are easily discoverable with specialized software or even by conducting a quick Google search.40 This means that previously unknown violations of rights can now be detected, which causes a dilemma for the party whose rights may have been violated by a third party: Should they enforce their rights or ignore the purported violation? One of the reasons for the overall rise in cease-and-desist letters in some areas of the law, like intellectual property, is the misconception that rights holders need to enforce each and every single perceived violation of their rights or they risk losing them. 41

The actual cease-and-desist letter process is fairly straightforward. After discovering a perceived legal right violation, an individual or entity sends a letter to the violator, identifying the entity's rights and the unlawful actions of the violator. The letter will demand that the violator cease and desist in its actions. ${ }^{42}$ Depending on the type of violation, the letter may demand

38. Julie Samuels, It's a Bad Week to be a Patent Troll: Big Updates from New York and Newegg, ELEC. FrONTIER FOUND. (Jan. 14, 2014), https://www.eff.org/deeplinks/2014/01/its-bad-week-bepatent-troll-big-updates-new-york-newegg.

39. See, e.g., Cease and Desist Letters, ABOvE THE LAW, http://abovethelaw.com/tag/ceaseand-desist-letters / (last visited Mar. 16, 2015) (showcasing abusive cease-and-desist letters covering various legal claims).

40. See, e.g., BitMatch, S.A.F.E., http://www.safe-corp.biz/products_bitmatch.htm (last visited Mar. 3, 2015).

41. Cf. Devan R. Desai \& Sandra L. Rierson, Confronting the Genericism Conundrum, 28 CARDOZO L. REV. 1789, 1833 (2007); 2J. ThOMAS MCCARTHY, MCGARTHY ON TRADEMARKS AND UNFAIR COMPETITION § 11:91 (4th ed. 2014).

42. There are a number of websites with template cease-and-desist letters. See, e.g., Cease \& Desist Letter Templates, Examples \& Sample Forms, ThOMPSOn Hall SANTI Cerny \& DOOley, http://thompsonhall.com/cease-desist-letter-template-example-sample-forms/ (last visited Mar. 16, 2015); Cease and Desist Letter Template, ROCKETLAWYER, https://www.rocketlawyer.com 
additional actions be taken (i.e., removal of defamatory language on a website).43 Additionally, the letter will typically contain a threat, either implicit or explicit, that if the target does not respond to the letter, the sender will investigate its legal remedies, which may include litigation. Upon receipt of the cease-and-desist letter, the recipient has a choice to either comply with the demands or fight back.44 Compliance is typically achieved through entering into some type of settlement agreement, whether through an affidavit of compliance by the target, or a more extensive negotiated agreement. ${ }^{45}$ Although there are no statistics available on the success rate of cease-and-desist letters, anecdotally, it appears that the vast majority of disputes begin and end with the cease-and-desist letter, particularly where the letter is abusive. 46

There are two noteworthy aspects of the typical cease-and-desist letter process. First, the cease-and-desist letter process is typically conducted between asymmetrical disputants. Although entities of all sizes enforce their legal rights, it appears that the larger the company, the more likely it is to initiate court action or arbitration. 47 The reason for this is that well-resourced entities typically have the funds to either hire outside legal counsel or maintain a staff of in-house attorneys. ${ }^{48}$ Second, as settlement is the typical outcome of cease-and-desist letters, the whole process is conducted outside of the judicial system. This fact raises the importance of non-judicially related laws and needed regulations in this area. However, there are currently no

/article/cease-and-desist-letter-template.rl (last visited Mar. 16, 2015).

43. The violation can vary from defamation, harassment, breach of contract, to infringement of an intellectual property right. See Cease \& Desist Letter Templates, Examples \& Sample Forms, THOMPSON HALL SANTI CERNY \& DOOLEY, supra note 42.

44. Defending oneself against a claim of legal rights violations can involve formal legal actions, like filing for a declaratory judgment, or informal actions, like public shaming. See Grinvald, supra note 15, at 631; see also Part III.B.1 (discussing declaratory judgment actions). The use of public shaming can be successful, however, it requires certain factors to be present for its success. Grinvald, supra note 15, at 666-67 (discussing the four factors required for a successful shaming campaign against a trademark bully).

45. See, e.g., Letter from Anessa Owen Kramer, Partner, Honigman, Miller, Schwartz \& Cohn LLP, to Jeff Britton, Owner, Exit 6 Pub and Brewery LLC (Dec. 9, 2013) (on file with author) (requesting written assurances of compliance to demands contained in letter); Settlement Agreement, Estate of James Joyce and Carol Loeb Shloss, Mar. 19, 2007, available at http://cyberlaw.stanford.edu/files/blogs/Shloss\%20Settlement\%20Agreement.pdf (settling copyright infringement claims).

46. See Gallagher, supra note 8 , at 478 .

47. Fulbright \& JaWORski LLP, SECOND ANNUAL Litigation Trends Survey: FINDINGS 8 (2005).

48. See Grinvald, supra note 15 , at 655-56. 
effective laws and regulations for cease-and-desist letters, placing a great deal of discretion upon the senders to appropriately draft such letters and negotiate a fair settlement. 49 Unfortunately, there are a variety of incentives that encourage sending abusive cease-and-desist letters in order to guarantee a non-judicial, or private, settlement.50 Prior to discussing these incentives, it is important to understand the elements that make a cease-and-desist letter "abusive."

\section{B. Defining Abusive Cease-and-Desist Letters}

While not all cease-and-desist letters are abusive, an informal review of cease-and-desist letters posted on public websites reveal that the average cease-and-desist letter is not a friendly, merit-worthy missive intended to encourage a non-adversarial or fair settlement. ${ }^{51}$ Contained within almost all cease-and-desist letters is a threat of litigation (either implicit or explicit). This threat alone does not cause the letter to be abusive; rather, it is this threat, combined with one or more factors that create the abuse. This section will outline four factors that can create an abusive letter, however, these factors are not exclusive and the absence of one factor does not automatically mean a letter is not abusive. Ultimately, it is the totality of the letter that determines its characterization.

\section{Inappropriate Legalese, or Other Harsh and Insulting Language}

Lawyers often write using legalese or "lawyerly" language.52 Using legalese may be appropriate at times, such as when quoting from a statute, 53 however, when communicating with non-lawyers, the legal profession has come to find that legalese is not only unnecessary, but often completely

49. See infra Part III (discussing the ineffectiveness of current enforcement efforts).

50. See infra Part II.B.

51. See, e.g., Cease and Desist Letters, ABOvE THE LAw, supra note 39 (showcasing abusive ceaseand-desist letters). This Article acknowledges that the letters that receive media attention are likely going to be reflective of extreme abuse, as to be deemed newsworthy.

52. "Legalese" is defined as "the specialized language of the legal profession that is [usually] complicated and often unintelligible to an outsider." WEBSTER's THIRD NEW INT'L DICTIONARY 1290 (unabr. ed. 1986).

53. Although some plain English activists would disagree with this. See Andy Mergendahl, Legal Writing in Plain English as Culture War, LAWYERIST (May 11, 2013), http://lawyerist.com/64667/legal-writing-in-plain-english-a-culture-wa/ ("[F]or a number of reasons, florid, complex writing strewn with legalese does a poor job of communicating, whether the reader is a lawyer, judge, or layperson (like a client)."”). 
unwarranted.54 For example, the Securities and Exchange Commission requires that disclosure documents are written in "plain English," and urges the profession to push for clarity in drafting all documents. 55 Distinguishing between appropriate legalese and inappropriate legalese is challenging; however, when a cease-and-desist letter is sent to a non-lawyer, this Article argues that using legalese is always inappropriate. There is no reason to use legalese other than as an intimidation tactic, and a cease-and-desist letter can easily convey its seriousness in plain English.

Additionally, inappropriate use of legalese also includes citing to legal authority without referencing the substance of the law 56 when the letter is sent to a non-lawyer. ${ }^{57}$ Similar to using Latin phrases or lawyerly language, lawyers cite to laws in an attempt to provide legitimacy to the legal claims. This tactic is particularly useful where the claims are meritless or weak. Where the letter is sent to another attorney, simply including a citation to the relevant law is warranted, as attorneys have the resources to find the citation. However, where the letter is sent to a non-lawyer, it is unlikely that the recipient will be able to access the cited law or have the resources to hire a lawyer to do so for them. 58 Therefore, legal citations without inclusion of the source are simply an attempt at intimidating the target to capitulate to the letter's demands.

While including a copy of the cited law in a cease-and-desist makes sense where it is sent to a non-lawyer, critics may argue otherwise. Critics may argue that even when the sender attaches a copy of the cited statute to the letter, it is unlikely that a non-lawyer target would be able to interpret the law due to the complicated language found in most statutes. While this criticism has merit, including a substantiated statutory citation gives the target the opportunity to read and attempt to interpret the law (or find a friend or family member to do so on their behalf).

Further, harsh or insulting language is also a contributing factor to

54. See, e.g., Nora Rock, Five Good Reasons to Avoid "Legalese," PRACTICEPRO (Jan. 16, 2014), http://avoidaclaim.com/2014/five-good-reasons-to-avoid-legalese/.

55. See generally U.S. Sec. \& ExCh. Comm'N, A Plain English Handbook: How to CREATE Clear SEG Disclosure DOCUMENTS (1998).

56. See Grinvald, supra note 15, at 628. Including quotations, hyperlinks, or attachments of the cited statutory authority are all acceptable methods of referring to the law.

57. See, e.g., Letter from Robert P. Ducatman, Partner, Jones Day, to Registrant of www.kevynorr.com (June 10, 2014) (on file with author) ("Continued unauthorized use of these marks constitutes, at a minimum, service mark infringement, service mark dilution, and false description in violation of 15 U.S.C. $\$ 1051$ et seq. and state law.”).

58. See Grinvald, supra note 15, at 648-49. 
determining whether a letter is abusive. In fact, the dictionary defines "abusive" as "employing harsh or insulting language."59 While using insulting language is not frequently seen in letters containing inappropriate legalese, it is important to note that harsh or insulting language is never appropriate in a letter asserting one's legal rights. 60

\section{Demands for Quick Settlement}

A demand to complete a transaction at once is the hallmark of a coercive settlement and is arguably one of the most common traits of abusive cease-and-desist letters. ${ }^{61}$ For example, in Odorizzi v. Bloomfield Sch. Dist. ${ }^{62}$ the California Court of Appeal noted the fact that Mr. Odorizzi was coerced into resigning his job because his employer demanded that he resign immediately, without time for reflection or outside counsel, was an important factor in potentially voiding the agreement. ${ }^{3}$ Typically, an abusive cease-and-desist letter demands that a target respond within a very short time frame, often between three and fourteen days.64 For example, one abusive letter stated, "The complaint is prepared, and we will file it next week if we do not receive an acceptable response from you [in five days]." 65 One week does not provide a target with any meaningful time to find an attorney. Even if a target were to retain an attorney, this type of short time frame does not allow the attorney to conduct a thorough analysis of the claims or prepare a response letter by the stated deadline. 66 In this situation, the only viable option for a target is to capitulate and accede to the demands of the letter, regardless of the legal merits of the claims.

While there is some value to the counter-argument that providing a short time frame in a cease-and-desist letter is necessary to ensure that a

59. WEBSTER'S THIRD NEW INT'L DICTIONARY 8 (unabr. ed. 1986).

60. See Model Rules of Prof'L Conduct Preamble (2013). A lawyer has the obligation to maintain "a professional, courteous and civil attitude toward all persons involved in the legal system.” Id.

61. The recently enacted state anti-patent troll laws also include this item as a factor in determining a "bad faith" assertion of patent infringement. See, e.g., IDAHO CODE ANN. § 481703(2)(d) (West 2014).

62. 54 Cal. Rptr. 533 (Cal. Dist. Ct. App. 1966).

63. See id. at 541 (characterizing the demand as exerting undue influence).

64. See, e.g., Letter from Robert P. Ducatman, supra note 57 (giving target three days to respond); Letter from Anessa Owen Kramer, supra note 45 (giving the target two weeks to respond).

65. Letter from Robert W. Payne, Attorney, LaRiviere, Grubman \& Payne LLP, to Michael Shkolnik (June 7, 2002) (on file with author).

66. See Grinvald, supra note 15, at 648-49. 
target takes the sender's demands seriously, other benchmarks provide enough time for retention of an attorney, and for the attorney to conduct a proper analysis and response. 67 For example, Rule 12 of the Federal Rules of Civil Procedure provides a minimum timeframe of twenty-one days for a defendant to respond to a newly filed summons and complaint.68 The circumstances of a newly sued defendant is similar to that of a cease-anddesist letter recipient - both need time to retain an attorney, and the attorney needs time to draft a response. Unlike cease-and-desist letter recipients, however, litigation defendants have an opportunity to request additional response time from the court. 69 Because the cease-and-desist letter process is extra-judicial, letter recipients do not have this ability. Therefore, a timeframe similarly given to litigating defendants, if not longer, is needed for the cease-and-desist letter process, and any letter demanding anything less than the standard twenty-one days should be considered abusive.

\section{Demands for Immediate Payment of Fees}

Similar to demanding settlement within a short timeframe, a demand for immediate payment of fees within a cease-and-desist letter is another factor that strongly favors characterizing the letter as abusive.70 The type of fees demanded differs depending on the particular claims. Some letters demand payment of licensing fees or attorneys' fees, in addition to the target's capitulation, in order for the sender to not file a lawsuit against the target. For example, the patent troll, MPHJ Technology, routinely sent cease-anddesist letters to small businesses demanding a license fee between $\$ 900$ and $\$ 1,200$ per employee in order for the target to continue to use its scanning technology.71 In essence, the demand for fees in exchange for not filing a lawsuit is akin to extortion, particularly where the sender of the letter has no

67. For example, the U.S. Patent \& Trademark Office (USPTO) typically provides trademark and patent applicants with six months to respond to an office action (a letter from an attorney at the USPTO regarding the application). See MPEP $\$ 710.01$ (9th ed. Mar. 2014).

68. FED. R. GIV. P. 12(a)(1)(A)(i).

69. FED. R. GIV. P. 6(b). While a request for additional time from the court may typically be made after the opposing party denies an extension, the ability to request the court for this additional time exists, and is not present in situations of cease-and-desist letters.

70. Also similar to the short time frame item, this item is also cited as a factor in determining a bad faith assertion of patent infringement in the recently enacted state anti-patent troll laws. See, e.g., IDAHO CODE ANN. § 48-1703(2)(d) (West 2014).

71. See Joe Mullin, Patent Trolls Want \$1,000 - For Using Scanners, ARs Technica JJan. 2, 2013), http://arstechnica.com/tech-policy/2013/01/patent-trolls-want-1000-for-usingscanners/. 
intention of filing a lawsuit.72 Some states recognize that extortion is actionable even where the threats are of unfounded civil prosecution.73

\section{Weak or Unreasonable Claims of Rights Violations}

"Weak" or "unreasonable" claims of rights violations are easy to identify at the extremes. For example, a claim alleging that a target had used the accuser's trademarks to sell counterfeit products (but were, in fact, advertising the resale of genuine products), is a weak claim. ${ }^{74}$ Another example is a claim, which alleges trademark infringement by a company that began using the mark after the alleged infringer. 75

Where weak or unreasonable claims become harder to identify are borderline claims. These types of claims, at first, may appear mildly plausible, but after applying the target's potential legal defenses, the claims become weak or even unreasonable. 76 For example, Louis Vuitton sent a cease-anddesist letter to the University of Pennsylvania School of Law (the "Law School"), claiming that a flyer publicizing the school's symposium on Fashion Law infringed and diluted Louis Vuitton's trademarks. ${ }^{77}$ The flyer's background consisted of a design that was reminiscent of the famous "LV" logo, but had been changed to "TM" and "®."78 At first, Louis Vuitton's claims seem plausible, as Louis Vuitton and the LV logo are famous trademarks, and the flyer's background clearly intended to evoke a

72. See Extortion Definition, Dictionary.COM,
http://dictionary.reference.com/browse/extortion (last visited Mar. 6, 2015) ("[T]he crime of obtaining money or some other thing of value by the abuse of one's office or authority.").

73. See, e.g., Monex Deposit Co. v. Gilliam, 666 F. Supp. 2d 1135, 1136-37 (C.D. Cal. 2009).

74. See Apple Computer Inc. v. Micro Team, No. C 98-20164 PVT, 2000 WL 1897354, at *7 (N.D. Cal. Dec. 21, 2000) ("Once the trademark holder sells his product, the buyer ordinarily may resell the product under the original mark without incurring any trademark liability.").

75. This is a weak claim because the alleged infringer would have "priority" under trademark law. Priority in trademark law is usually determined by which party first uses the mark in commerce. Hana Fin., Inc. v. Hana Bank, 135 S. Ct. 907, 909 (2015).

76. See Lara Pearson, Alex Butterman, Leah Chan Grinvald, Natalie Sulimani \& Chris Wheeler, 'Trademark Bullying'-Time to Get Some Clear Definitions, 44 WORLD Trademark REv. 92, 94 (Aug.-Sept. 2013) (discussing the Louis Vuitton example).

77. See Letter from Michael Pantalony, Dir. of Civil Enforcement, Louis Vuitton Malletier, to Michael A. Fitts, Dean, University of Pennsylvania Law School (Feb. 29, 2012), available at https://www.law.upenn.edu/fac/pwagner/DropBox/lv_letter.pdf. The language used in the letter is insulting: "I would have thought the Penn Intellectual Property group, and its faculty advisors, would understand the basics of intellectual property law and know better than to infringe and dilute the famous trademarks of fashion brands, including the LV Trademarks, for a symposium on fashion law." Id.

78. See id. (including the flyer as Exhibit A). 
connection to the brand since the symposium's topic was fashion law. ${ }^{79}$ Due to this superficial plausibility, an Associate Dean at the Law School requested that the students immediately change the flyer.80 However, on closer inspection of both the letter's claims and the Law School's use of the LV logo, it became more apparent that neither a likelihood of confusion 81 was present, nor was the Law School using the mark for a commercial purpose.82 After the Associate General Counsel of the Law School sent Louis Vuitton an explanation of its defenses, Louis Vuitton dropped its claim. 83

Asserting weak or unreasonable claims establishes a cease-and-desist letter as abusive because it takes advantage of the legal system, particularly when the sender knows its claims have little or no merit. In such situations, the sender is unlikely to file a lawsuit against the target, or if such lawsuit is filed, it is likely frivolous. ${ }^{84}$ To effectuate its demands, the sender depends on the target's desire to avoid the stress of litigation (where the target is a wellresourced entity), or the target's fear and ignorance of litigation (where the target is a low-resourced entity, such as a small business or individual). 85

79. See 15 U.S.C. $\S 1125(\mathrm{c})(2)(\mathrm{A})(2012)$ ("[A] mark is famous if it is widely recognized by the general consuming public of the United States as a designation of source of the goods or services of the mark's owner.").

80. See Letter from Robert F. Firestone, Assoc. Gen. Counsel, University of Pennsylvania Law School, to Michael Pantalony, Dir. of Civil Enforcement, Louis Vuitton Malletier (Mar. 2, 2012), available at https://www.law.upenn.edu/fac/pwagner/DropBox/penn_ogc_letter.pdf (referencing the email sent by Steven Barnes, Associate Dean for Communications of the University of Pennsylvania Law School).

81. See 15 U.S.C. $\$ 1125$ (a)(1) (2012) ("Any person who ... uses in commerce any word, term, name, symbol ... which . . . is likely to cause confusion, or to cause mistake, or to deceive as to the affiliation, connection, or association of such person with another person, or as to the origin, sponsorship, or approval of his or her goods, services, or commercial activities by another person ... shall be liable in a civil action by any person who believes that he or she is or is likely to be damaged by such act.").

82. See id. § 1125(c)(3) ("The following shall not be actionable as dilution by blurring or dilution by tarnishment under this subsection ... (C) Any noncommercial use of a mark.").

83. See Letter from Robert F. Firestone, supra note 80.

84. For example, the troll, MPHJ Technology, sent initial cease and desist letters to over 16,000 small businesses from December 2012 to May 2013. See Joe Mullin, Patent Stunner: Under Attack, Nation's Most Notorious "Troll" Sues Federal Gov't, ARS TeCHNICA (Jan. 14, 2014), http://arstechnica.com/tech-policy/2014/01/patent-stunner-under-attack-nations-most-

notorious-troll-sues-federal-govt/. After over a year of threats, MPHJ filed its first actual lawsuit in November 2013. See Joe Mullin, Notorious "Scan-to-Email" Patents Go Big, Sue Coca-Cola and Dillard's, ARS TECHNICA (Jan. 6, 2014), http://arstechnica.com/tech-policy/2014/01/notorious-scan-toemail-patents-go-big-sue-coca-cola-and-dillards/.

85. See Mullin, supra note 71 (reporting that one targeted company acceded to the demands of a patent troll without asking any questions in order to avoid conflict while it was in the process of being acquired). 
Unfortunately, a number of incentives motivate senders to distribute abusive cease-and-desist letters. ${ }^{86}$ Where the targets of abusive cease-anddesist letters are low-resourced entities, policy makers and the legal community should be concerned about the effectiveness of abusive ceaseand-desist letters causing numerous de facto coerced agreements, a reduction in marketplace competition, and an increase in private censorship of speech.

\section{Gharacteristics, Incentives, and Problems}

Some advocates of the private settlement process argue that resolving legal disputes without litigation is beneficial because it reflects the projected outcome of a judicial trial without imposing costs on society. ${ }^{87}$ Litigation is expensive, particularly in the intellectual property area. 88 Therefore, as a theoretical matter, private settlements could be beneficial to society. 89 However, this is not the case in situations of asymmetrical disputants. The argument that a private settlement merely projects the outcome of litigation is premised on a faulty assumption of symmetrical bargaining power. 90 Disputes occur between and among parties of all sizes. Where there is economic or social disparity between the disputing parties, unregulated private settlements are likely to be considered coercive and not beneficial to society, as noted by Yale Law Professor Owen Fiss in his influential Comment entitled, "Against Settlement."91

Professor Fiss argues that three characteristics of low-resource litigants affect the settlement process, which increases the probability of settlement: (1) an inability to information-gather, (2) a susceptibility to inducement, and (3) an inability to finance the litigation.92 Due to these traits, Professor Fiss argues that private settlements are not appropriate because of the lack of

86. See infra Part II.B.

87. See Richard A. Posner, The Cost of Rights: Implications for Central and Eastern Europe-And for the United States, 32 TULSA L.J. 1, 2 (1996) ("The enforcement of legal rights consumes real resources, including ... indirect costs to the extent that rights are enforceable against socially productive activities, or impose socially burdensome duties, or protect socially harmful activities.").

88. See AM. Intell. Prop. LAW Ass'N, Report OF THE ECONOMIC SURVEy 34-36 (2013) [hereinafter AIPLA 2013 REPORT] (reporting that in 2013, costs associated with intellectual property litigation ranged from $\$ 300,000$ to $\$ 6,000,000$, depending on the type of case and value).

89. See generally Louis Kaplow, Private Versus Social Costs in Bringing Suit, 15 J. LEGAL STUD. 371 (1986) (discussing the externalities to society from private litigation).

90. Owen M. Fiss, Against Settlement, 93 YaLe L.J. 1073, 1076 (1984).

91. Id.

92. Id. 
judicial involvement in the process. ${ }^{93}$ Coupled with the incentives to send abusive cease-and-desist letters, low-resourced targets are left vulnerable to a coercive settlement process that begins with an abusive cease-and-desist letter.

Coercion is considered an anathema in the law, and theoretically coerced settlements are recognized as ineffective manifestations of consent. 94 Practically, coerced settlements generated from abusive cease-and-desist letters are detrimental to society because they reduce market competition, and consequently, consumer choice. 95 Additionally, abusive cease-and-desist letters chill free speech and provide private parties with a mechanism for censoring unfavorable speech. 96

\section{A. Characteristics of Small Businesses and Individuals}

Although Professor Fiss's Comment primarily focuses on the characteristics of low-resourced litigation plaintiffs, the same characteristics apply in the cease-and-desist letter process, where the concern is on lowresourced targets, namely small businesses or individuals. As stated above, these two populations share the same characteristics that often lead to a quick settlement, regardless of the merits. 97

\section{Inability to Information-Gather}

Information regarding the legal aspects of a dispute, such as the relevant laws and cases, is needed in order to effectively assess one's chances of success in a legal dispute. Just as crucial, however, is the non-legal information regarding the opposing party, such as the resources of the other party and the party's penchant for litigation. All of this information should be assessed together to formulate a strategy for the dispute (whether to send a demand

93. See id. at 1077-78.

94. RESTATEMENT (SECOND) OF CONTRACTS § 175(1) (1981) ("If a party's manifestation of assent is induced by an improper threat by the other party that leaves the victim no reasonable alternative, the contract is voidable by the victim."). See LON L. FULLER \& MELVIN ARON EISENBERG, BASIC CONTRACT LAW 292 (8th ed. 2006) ("It must, to constitute a contract, appear that two minds were at one ....”) (quoting Dickinson v. Dodds, 2 Ch. D. 463, 472 (1876)).

95. See Marcus Wohlsen, Patent Trolls are Killing Startups-Except When They're Saving Them, WIRED (Sept. 10, 2013), http://www.wired.com/2013/09/patent-trolls-versus-startups/ (reporting on the lawsuit filed by 1-800-Contacts against Ditto, a small startup competitor). See also infra Part II.C.2.

96. See Rebecca Curtin, SLAPPing Patent Trolls: What Anti-Trolling Legislation Can Learn from the Anti-SLAPP Movement, 18 STAN. TECH. L. REV. (forthcoming 2015) (on file with author).

97. See infra Part II.C.3 
letter, bring or defend a lawsuit, settle, etc.).98 For example, a party with a strong legal claim facing an opponent without a litigious reputation should maintain a strong negotiating position. However, if the opposing party is litigious and well-resourced, then it may be more advantageous for the claimant to settle. But conducting effective information-gathering to obtain this information consumes resources, particularly, financial resources, of which a low-resourced entity likely has little.99 Therefore, upon receipt of a cease-and-desist letter, a small business or individual would likely make a relatively uninformed decision to merely comply with the letter's demands. 100

\section{Susceptibility to Inducement}

For small businesses and individuals, a cease-and-desist letter may not only be an ominous sign of expensive legal bills, but also an emotional firestorm. Over 78 percent of all small businesses in the United States are sole proprietors. 101 This means that for the majority of small businesses, the only employee is the business owner herself. 102 Based on this information, a cease-and-desist letter could be viewed as a personal attack on the business proprietor, rather than an impersonal business interaction. For example, one small business owner who received a cease-and-desist letter from the National Football League stated that the letter initially "scared the bejesus out of [her]." 103 This leaves a small business or individual emotionally more susceptible to inducement to settle the legal dispute privately.

\section{Follow-through}

The appeals process is one aspect of the U.S. judicial system that increases the costs of litigation. ${ }^{104}$ Even if a party wins at the trial court level,

98. See Bret Rappaport, A Shot Across the Bow: How to Write an Effective Demand Letter, 35 J. Ass’N LEGAL WRITING DiR. 32, 36-37 (2008).

99. See Grinvald, supra note 15, at 649. While some small businesses may have business insurance that could cover intellectual property infringement litigation, it is highly unlikely that individuals (such as bloggers or artists) would have insurance coverage for such claims. See id. at 649 n. 141 .

100. See generally Robert G. Bone, Modeling Frivolous Suits, 145 U. PA. L. REV. 519 (1997) (providing examples an explanations regarding this asymmetrical information model).

101. See Grinvald, supra note 15, at 654 .

102. Id. at $654-55$.

103. Melinda Deslatte, 'Who Dat' Shirts CAN Be Sold: NFL Clarifies Saints Gear Position, HUFFINGTON POST (Apr. 3, 2010), http://www.huffingtonpost.com/2010/02/01/who-datshirts-can-be-sol_n_445291.html.

104. See Kim Tung, Reducing the Costs of Litigation: Appeals, Pub. LAw Research InST., 
there are generally two levels of appeals that the case could go through. 105 Even if a low-resourced entity is able to finance a lawsuit through the trial court proceeding, it may not be able to follow the case through on appeal. Additionally, once a lawsuit has begun, defendants at all stages have difficulty withdrawing without the consent of the plaintiff (which often comes at a high cost, if at all).106 Further, the consequences for not defending oneself are harsh - default judgment.107 This means that a low-resourced entity is likely to settle early, even if it has a strong defense, as it would be unlikely to have the funds to defend itself to the end of the litigation.

Based on these three characteristics, Professor Fiss argues that private settlements between asymmetrical parties are inherently coercive and cautions against a wholesale adoption of rules that force parties to privately settle their legal disputes. 108 This Article takes a more nuanced approach to private settlements between parties with resource disparity, and argues that the three characteristics place low-resourced entities at greater risk for coercive settlements. However, not all private settlements between unequal parties are necessarily coercive; instead, in the cease-and-desist letter process, it is the abusive letter combined with the asymmetry and the three characteristics that creates the coercion. The question then becomes one of why: Why would someone want to send an abusive letter?

\section{B. Incentives}

There are a number of economic, legal, and practical factors that incentivize entities to knowingly send abusive letters to small businesses and individuals. Four notable factors are (1) the costs of litigation and (2) its uncertainty, (3) the lack of legal consequences for sending abusive letters, and (4) the letter's effectiveness in obtaining the desired outcome.

http://gov.uchastings.edu/public-law/docs/plri/appeal.pdf (last visited Feb. 20, 2015). Tung's article poses the questions: "What is wrong with the appellate system?" and "Why does it cost so much, but run so slowly?" See id.

105. See U.S. Court System, Syracuse Univ. Maxwell Sch. Of Citizenship \& Pub. AFFAIRS, http://www2.maxwell.syr.edu/plegal/scales/court.html (last visited Mar. 7, 2015). Even if the case is administrative, like an inter partes patent reexamination, the cost of seeing the case through to appeals is quite high, relative to the initial costs $(\$ 50,000$ versus $\$ 250,000)$. AIPLA 2013 REPORT, supra note 88 , at 36.

106. See generally FED. R. CIV. P. 12(a)(1)(A) (“A defendant must serve an answer ....") (emphasis added).

107. FED. R. CIV. P. 55(a) ("When a party against whom a judgment for affirmative relief is sought has failed to plead or otherwise defend, and that failure is shown by affidavit or otherwise, the clerk must enter the party's default.").

108. Fiss, supra note 90, at 1075. 


\section{Costs of Litigation}

The economic costs of litigation have been widely discussed in academic and policy literature.109 Engaging in litigation is expensive and timeconsuming. For example, an average infringement lawsuit for a patent valued at less than $\$ 1$ million costs $\$ 350,000$ to $\$ 700,000$ to litigate, without accounting for any appeals. 110 Part of the expense of litigation is the time it takes from initiation to verdict.111 One empirical study of federal courts found that the average length of a civil lawsuit ranged from one to two years during the period of 1971-86.112 Generally, a sender of cease-and-desist letters is aware of these costs, as it is oftentimes a target itself. 113

For example, Intel is both a major enforcer of its intellectual property rights as well as a target of others' enforcement efforts. Intel estimates that it receives between 100 and 150 cease-and-desist letters per month from patent holders claiming that it infringes on their rights. 114 Due to the high costs of litigation, rights holders have a strong incentive to resolve disputes privately through cease-and-desist letters. 115 While the costs of privately resolving an intellectual property rights dispute are unknown, it is likely much less expensive than litigation. 116 Therefore, there is a high economic incentive for targets to settle immediately upon receiving a cease-and-desist letter.

\section{Uncertainty of Litigation}

In addition to the high costs of litigation, the uncertain outcome presented by many types of claims is another incentive to send cease-anddesist letters. Particularly, litigation outcomes in intellectual property disputes are hard to predict, even for seasoned litigators. The reason for this difficulty differs for each area of intellectual property. For example, in patent

109. See, e.g., Posner, supra note 87, at 2; Kathleen Engelmann \& Bradford Cornell, Measuring The Cost of Corporate Litigation: Five Case Studies, 17 J. LeGAL STUD. 377, 378-88 (1988); David M. Trubek et al., The Costs of Ordinary Litigation, 31 UCLA L. REV. 72 (1993).

110. See AIPLA 2013 REPORT, supra note 88, at 34.

111. See Terence Dungworth \& Nicholas M. Pace, Statistical Overview Of Civil LITIGATION IN THE FEDERAL COURTS 16 (1990) (discussing the concern regarding caseload increases in federal district courts leading to delay and a consequent denial of justice to the parties).

112. Id. at 20 .

113. See Trimble, supra note 7, at 787 (discussing the following Intel example).

114. Id. (citing Intel's General Counsel).

115. See FUlBRIGHT \& JAWORSKI LLP, supra note 47, at 15 (listing intellectual property disputes as one of the most costly types of litigation).

116. See id. 
cases, some of the uncertainty stems from the claim construction that the district court adopts during a "Markman" hearing, ${ }^{117}$ whereas in trademark law, the uncertainty can stem from the various defenses a defendant may have, or the strength of the plaintiff's mark.118 Additionally, rights holders may be apprehensive about enforcing a claim in court due to the court's ability to invalidate intellectual property rights. ${ }^{119}$ Similar to the high costs of litigation, outcome uncertainty incentivizes rights holders to ensure that they privately settle with the targets of their letters.

\section{Effectiveness}

While the empirical data on the effectiveness of abusive cease-and-desist letters is fairly non-existent, anecdotal evidence emphatically supports the conclusion that abusive letters are effective particularly when they are sent to low-resourced entities, such as small businesses and individuals. ${ }^{20}$ The reason for such effectiveness is the confluence of factors discussed abovethe abusive language contained in the letter, asymmetrical disputants, and the characteristics of the low-resourced entities121 — that creates a coercive

117. Markman v. Westview Instruments, Inc., 517 U.S. 370, 390 (1996) ("[W]e see the importance of uniformity in the treatment of a given patent as an independent reason to allocate all issues of construction to the court."). See also Edward Brunet, Markman Hearings, Summary Fudgment, and Fudicial Discretion, 9 LEWIS \& CLARK L. REV. 93, 104 (2005) ("The early interpretation of the scope of a patent claim can be used for subsequently deciding issues of both patent validity and infringement."); David v. Goliath: Clinic Takes Early Victory Against Lowe's, SUFFOLK UNIV. LAW SCH. (June 4, 2014), http://www.suffolk.edu/news/52901.php ("[C]laim construction defines the scope of the patent and, in many cases, can greatly influence the ultimate outcome of the case.").

118. See Grinvald, supra note 15 , at $638,660-61$. The scope of trademark protection is based on the strength of the trademark. $I d$. at 638 . The stronger the trademark is, the wiper scope of protection. Id.; see also E. \& J. Gallo Winery v. Gallo Gattle Co., 967 F.2d 1280, 1291 (9th Cir. 1992) ("The strength of a mark is determined by its placement on a "continuum of marks from "generic," afforded no protection; through "descriptive" or "suggestive," given moderate protection; to "arbitrary" or "fanciful" awarded maximum protection.") (quoting Nutri/System, Inc. v. ConStan Indus., Inc., 809 F.2d 601, 605 (9th Cir. 1987)). Compare Family Circle, Inc. v. Family Circle Assocs., Inc., 332 F.2d 534, 540-41 (3d Cir. 1964) (holding that the "Family Circle" trademark was not strong enough to enjoin unauthorized third-party uses in product categories other than in the plaintiff's business of magazines), with The Wet Seal, Inc. v. FD Mgmt., Inc., 82 U.S.P.Q.2D (BNA) 1629, 1641-42 (T.T.A.B. 2007) (holding that "Arden B" was a famous trademark and the plaintiff could enjoin third-party uses of the mark in product categories outside of plaintiff's products).

119. See, e.g., Christian Louboutin S.A. v. Yves Saint Laurent Am., Inc., 778 F. Supp. 2d 445, 457 (S.D.N.Y. 2011) (holding that plaintiff's trademark for its "Red Sole" was non-distinctive and ordering its cancellation), rev'd in part, 696 F.3d 206, 228 (2d Cir. 2012) (overturning the district court's decision on non-distinctiveness, but limiting the trademark to where the Red Sole is contrasted with the outside color of the shoe).

120. Gallagher, supra note 8, at 478.

121. See supra Parts I.B.1-4, II.A. 
environment where the low-resourced entity has no choice but to accede to the demands of the cease-and-desist letter. It is important to note that abusive cease-and-desist letters are also effective when sent to well-resourced entities. This may be attributed to a number of factors, but for some well-resourced entities, the costs (financial and human capital) of engaging in litigation may outweigh any benefit obtained by receiving a favorable outcome.122 While abusive letters are problematic even if the disputants are in symmetry, this situation is not overly worrisome because there is no coercion. Wellresourced parties are able to information-gather in order to make an informed decision to settle with an intellectual property rights holder. 123

\section{Lack of Legal Consequences}

Due to its extra-judicial nature, abusive cease-and-desist letters do not come within the purview of the legal protections against abusive litigants, such as the Federal Rules of Civil Procedure Rule 11 sanctions. ${ }^{124}$ Outside of the judicial sphere, abusive cease-and-desist letters do not squarely fit within other regulatory schemes. One exception is where a patent troll sends an abusive letter in bad faith.125 This narrow situation directly implicates recent legislation passed by approximately twenty-two states, but as discussed in Part III.C, this legislation would not assist where the abusive letter was sent in good faith. 126

122. See Theodore H. Davis, Jr., Recovery of Attorneys' Fees in Trademark and Unfair Competition Litigation, 2 LANDSLIDE 14, 17 (May-June 2010) (concluding that since the possibility of attorneys' fees may influence the decision to settle, attorneys need to take into consideration that attorneys' fee awards are a low likelihood in trademark litigation). Willingness to settle is particularly the case in intellectual property law where judges have the discretion to impose attorneys' fees on the losing party in "exceptional cases." 15 U.S.C. $\$ 1117$ (a) (2012). Imposing attorneys' fees is not the norm, and judges go out of their way to deny such awards. See, e.g., Phillip Morris USA Inc. v. Lee, 547 F. Supp. 2d 685, 697 (W.D. Tex. 2008) (declining to award fees despite finding of willful infringement in context of award of statutory damages); Reno Air Racing Ass'n v. McGord, 76 U.S.P.Q.D.2d (BNA) 1302, 1309 (D. Nev. 2004) (declining to award fees despite defendant's continued infringement in violation of temporary restraining order), rev'd in part on other grounds, 452 F.3d 1126 (9th Cir. 2006). See also Davis, supra, at 14.

123. Furthermore, a well-resourced party may be able to negotiate a coexistence agreement depending on the claims of the intellectual property rights holder. See Marianna Moss, Trademark "Coexistence" Agreements: Legitimate Contracts or Tools of Consumer Deception?, 18 LOY. CONSUMER L. REV. 197, 199 (2005) ('In order to coexist in the market 'peacefully,' companies with potentially infringing trademarks sometimes enter into coexistence agreements, which allow them to continue marketing their products to the public without the fear of defending a trademark infringement lawsuit.”).

124. See infra Part III.B.2.

125. See Patent Progress's Guide to State Patent Legislation, supra note 21.

126. See id. (identifying the following states as having passed legislation addressing bath faith 
Aside from the narrow anti-patent troll laws, the only legal consequence for sending abusive cease-and-desist letters appears to be remote: the risk that the target files for a declaratory judgment action or publicly shames the sender. Unfortunately, it is unlikely that a small business or individual will be able to file a declaratory judgment action against a sender of an abusive cease-and-desist letter due to the high costs involved.127 While public shaming is a low-cost alternative to litigation and can be an effective bargaining tool, a number of variables contribute to its success. 128 Therefore, shaming may not be available to all targets of abusive cease-and-desist letters. Additionally, recent work on prospect theory and the endowment effect shows that some senders of abusive cease-and-desist letters may not be rational actors, and, as a consequence, are likely unshamable.129 As a result, there are currently few, if any, direct legal consequences from sending an abusive cease-and-desist letter. While some forms of regulation could police abusive cease-and-desist letters, it is necessary to understand the problems associated with abusive cease-and-desist letters.

\section{Why are Abusive Cease-and-Desist Letters Problematic?}

This Article has established that cease-and-desist letters may lead to coerced settlement agreements. 130 Coercion is problematic on many different levels. Philosophically, coercion in a negotiation process invalidates any resulting agreement on moral grounds. 131 However, due to the characteristics

patent infringement assertions: Alabama, Georgia, Idaho, Illinois, Louisiana, Maine, Maryland, Mississippi, Missouri, Montana, New Hampshire, North Carolina, North Dakota, Oklahoma, Oregon, South Dakota, Tennessee, Utah, Vermont, Virginia, Washington, and Wisconsin). See, e.g., GA. CODE ANN. § 10-1-771(a) (West 2014) ("A person shall not make a bad faith assertion of patent infringement.").

127. See infra Part III.B.1.

128. Some of these variables are shared norms of a community in which the target of shaming is a part, and the vulnerability to shaming by the shaming target. Grinvald, supra note 15, at 666-68.

129. See Jessica M. Kiser, To Bully or Not to Bully: Understanding the Role of Uncertainty in Trademark Enforcement Decisions, 37 COLUM. J.L. \& ARTS 211, 242 (2014) ("Calling the trademarks 'crown jewels,' or viewing them as on par with tangible property, illustrates the tendency of trademark owners to elevate the status of trademarks to something more significant than mere business assets. The inherent nature of trademarks lends itself easily to the errors associated with the endowment effect. Since this psychological effect can impact rational decision making, it should be taken into consideration by anyone seeking to deter trademark bullying.”).

130. See supra text accompanying note 20.

131. See Claire Finkelstein, Contract Under Coercion: Should You Keep a Contract with a Robber? 3 (Sept. 30, 2010) (unpublished manuscript), available at https://www.law.berkeley.edu/files/Contracts_Under_Coercion_CFinkelstein_093010.pdf; Mark Fowler, Coercion and Practical Reason, 8 SOC. THEORY \& PRAC. 329, 330 (1982). 
of low-resourced entities, it is unlikely that a coerced agreement would be invalidated - creating de facto enforcement. Economically, an agreement based on coercion is anti-competitive and reduces consumer choice in the marketplace. More generally, abusive cease-and-desist letters are problematic because they increase the power of private censorship by wellresourced entities.

\section{Coercion Invalidates}

It is well-settled contract doctrine that coercion invalidates agreements. 132 The theoretical rationale for this is that coercion clouds the free will and the thought process of the coerced party, such that the consent given is invalid. 133 Under this reasoning, even if the choice made by the coerced party is advisable or intentional, the choice is still invalid because of the coerced party's inability to freely decide that for herself. 134 Abusive ceaseand-desist letters sent to small businesses and individuals are clearly coercive because the goal of an abusive letter is to cloud the free will and thought process of the low-resourced recipient. The use of unnecessary legalese and unsubstantiated statutory citations are intended to confuse and intimidate the non-attorney recipient of the letter. Additionally, the demand for immediate settlement within an unreasonable timeframe implies that no outside advisors would be allowed to provide support to the low-resourced entity.

Further, the demands provided in the letter approximate extortion. 135 The threat of litigation, combined with one of the other indicia of abusiveness, ${ }^{136}$ provides the low-resourced entity with a choice of either complying or facing expensive litigation. This choice may come down to the decision between staying in business or the value received by keeping a secret

132. See Oren Bar-Gill \& Omri Ben-Shahar, Credible Coercion, 83 Tex. L. Rev. 717, 718 n.1 (2005); Robert L. Hale, Bargaining, Duress, and Economic Liberty, 43 Colum. L. Rev. 603, 616-17 (1943).

133. See Alan Wertheimer, COERCION 8 (1987) ("[C]oercion compromises or negates the voluntariness of an act ...."); Hale, supra note 132, at 616 ("[W] here there exist coercion . . . there is no volition. There is no intention nor purpose, but to yield to moral pressure, for relief from it.").

134. See Miller v. Fenton, 474 U.S. 104, 116 (1985); Lyons v. Oklahoma, 322 U.S. 596, 601 (1944).

135. See David B. Parker \& David D. Yang, Pre-Litigation Demand Letters: Assessing the Thin Line Between Zealous Advocacy and Extortion, 32 L.A. CNTY. BAR ASSOC. UPDATE, Dec. 2012, http://www.lacba.org/showpage.cfm?pageid=14413; Max Kennerly, When Does a Laweyer's Demand Letter Become Extortion?, LITIGATION \& TRIAL (July 19, 2013), http://www.litigationandtrial.com/2013/07/articles/attorney/demand-letter-extortion/.

136. See supra Parts I.B.1-4. 
safe. These options are not valid because the damage that could ensue from the expensive litigation is much greater than the perceived value of settling.

Some critics may argue that a low-resourced target should simply enter into the coerced agreement and then subsequently bring a lawsuit to invalidate that agreement based on the coercion, such as in the seminal cases Totem Marine Tug \& Barge, Inc. v. Alyeska Pipeline Serv. Co. 137 and Alaska Packers' Ass'n v. Domenico. ${ }^{138}$ For example, in Totem Marine, the plaintiff had previously entered into a settlement agreement with Alyeska Pipeline in order to avoid bankruptcy. After it was able to financially stabilize itself, it brought a lawsuit against Alyeska Pipeline to invalidate the earlier agreement. However, this is not a viable option for many low-resourced entities. The inability of small businesses and individuals to follow through on litigation means that this population does not have the resources needed to defend or prosecute a civil lawsuit, and such legal action is needed in order to invalidate coerced settlement agreements. This inability results in a form of de facto enforceability, which should be viewed as morally and legally undesirable.

\section{Anti-Competitiveness}

Economically, abusive cease-and-desist letters sent to small businesses and individuals are anti-competitive and harms consumer choice. In the marketplace, it is often the small businesses and individuals who provide competition to the established businesses in any particular industry, often by offering cheaper or cutting-edge alternatives. For example, a dog toy company, Haute Diggity Dog, made chewable dog toys called "Chewy Vuiton," that cost approximately $\$ 10$, whereas the trademark holder, Louis Vuitton, sold dog accessories costing approximately $\$ 1,600.139$ Additionally, individual bloggers that write product reviews or commentary aid small

137. 584 P.2d 15 (Alaska 1978). In Alyeska Pipeline Serv. Co., the plaintiff previously agreed to a settlement in return for a severe reduction in payment that was owed under the prior contract. $I d$. at 18. The plaintiff agreed to the settlement because they needed the quick infusion of cash, or else they would have gone bankrupt. Id. The court ruled that the settlement agreement had been coerced under the doctrine of economic duress and invalidated the agreement, paving the way for the plaintiff to potentially recover the full amount owed under the prior contract. Id. at 23-25.

138. 117 F. 99 (9th Cir. 1902). Interestingly, the court in Alaska Packers' Ass'n did not base its holding on the doctrine of coercion, but rather on the pre-existing duty rule. Id. at 103 . However, the case has been re-explained by Professor Finkelstein in terms of coercion. See Finkelstein, supra note 131 , at $42-48$.

139. See Peter Lattman, "Chewy Vuiton" Beats Louis Vuitton, But Feels a Bite, WALL ST. J. LAW BLOG (Nov. 28, 2006), http://blogs.wsj.com/law/2006/11/28/chewy-vuiton-beats-louis-vuittonbut-feels-a-bite/; Louis Vuitton Malletier S.A. v. Haute Diggity Dog, LLC, 507 F.3d 252, 268 (4th Cir. 2007). 
businesses in increasing exposure and further facilitate marketplace competition.140 Cheaper, or different, products, and candid reviews are helpful to consumers, as they provide increased choice and information.

The effectiveness of abusive cease-and-desist letters results in a reduction in competition, particularly where the letter alleges a violation of intellectual property rights. Patents, copyrights, and trademarks are often embedded within a product or service. Where the abusive cease-and-desist letter requires a complete abstention of future production or sales of a product or service or alternatively pay an outrageous license fee, a lowresourced entity may choose to simply discontinue the product. For example, the previously mentioned Haute Diggity Dog's entire line of dog toys were parodies of famous trademarks. When Louis Vuitton sued them for trademark infringement, the small business defended itself because, otherwise, in the words of one employee, "we would have had to go out of business." 141 Unfortunately, even though practitioners acknowledge this anticompetitive aspect of intellectual property enforcement, it is often not actionable or successful under antitrust law. ${ }^{142}$

\section{Private Gensorship ${ }^{143}$}

A more general concern is the effect that abusive cease-and-desist letters have on the freedom of low-resourced entities to express themselves. One example involves the blog, kevynorr.com, which criticized the actions taken by Kevyn Orr, a former partner at the large law firm, Jones Day, in handling

140. Eric Goldman, Online Word of Mouth and Its Implications for Trademark Law, in TRADEMARK LAW AND TheORY: A HANDBOOK OF CONTEMPORARY RESEARCH 409-10 (Graeme B. Dinwoodie \& Mark D. Janis eds., 2008).

141. Lattman, supra note 139 (quoting a Haute Diggity Dog employee).

142. Grinvald, supra note 15, at 650 (stating that trademark bullying will not fall within the purview of antitrust law because a trademark is unlikely to generate market power, which is a main requirement for an antitrust cause of action). See also Michael Lipkin, Lens.com's Antitrust Suit Against 1-800 Contacts Dismissed, LAw360 (Mar. 3, 2014), http://www.law360.com/articles/514963/lenscom-s-antitrust-suit-against-1-800-contacts-dismissed ("U.S. District Judge David Sam dismissed Lens.com's suit with prejudice, following the Tenth Circuit's decision last year in a related case that 1-800 Contacts' trademark claims were not baseless.").

143. While private censorship is not inherently unconstitutional due to the lack of state action, it is problematic in its own right. See Charles R. Lawrence III, If He Hollers Let Him Go: Regulating Racist Speech on Campus, 1990 DUKE L.J. 431, 444-49 (1990) (discussing the public versus private action distinction). Intellectual property law's harmful effect on free speech has been the topic of extensive academic discussion and the full range of arguments is outside the scope of this Article. For more in-depth coverage see Lisa P. Ramsey, Descriptive Trademarks and the First Amendment, 70 TENN. L. Rev. 1095, 1162-64 (2003); William McGeveran, Rethinking Trademark Fair Use, 94 IowA L. REV. 49 (2008); Ridgway, supra note 19, at 1571-78. 
Detroit's bankruptcy restructuring. ${ }^{144}$ The law firm sent the blog an abusive cease-and-desist letter with the intent to stop the negative criticism.145 Such criticism, while perhaps hurtful to Jones Day, serves an important function in our democratic society. Had the Electronic Frontier Foundation, a nonprofit organization, not stepped in to provide free legal counsel to the blog owners, it is likely that the criticism would have been taken down.146 More common, however, is for the low-resourced target to simply end its speech or censor itself ex ante. This results in an implicit authorization of private censorship, and where the targets are small businesses and individuals, regulation is clearly needed.

\section{Regulation of Abusive Cease-and-Desist Letters?}

Although cease-and-desist letters are typically private, there are a number of regulations or statutes that could serve to police abusive letters. These include legal ethics rules, judicial protections against abusive litigants, state anti-patent troll legislation, and consumer protection laws.

\section{A. Legal Ethics Rules}

All attorneys have a unique responsibility to maintain the integrity and competence of the legal profession 147 and are subject to the particular ethical rules established by the state where they are barred.148 Almost all states implement rules that closely resemble the American Bar Association's (ABA) Model Rules of Professional Conduct, 149 thus analyzing the applicability of

144. Joe Patrice, Biglaw Firm Throwes Even Bigger Hissy Fit, ABOve THE LAW (June 20, 2014), http://abovethelaw.com/2014/06/biglaw-firm-throws-even-bigger-hissy-fit/.

145. Letter from Robert P. Ducatman, supra note 57; see also Daniel Nazer, EFF to fones Day: Don't be a Trademark Bully, Elec. FronTier Found. (June 24, 2014), https://www.eff.org/deeplinks/2014/06/eff-jones-day-dont-be-trademark-bully.

146. The blogger may have been coerced into taking down the site, as the cease-and-desist letter is very abusive. For example, it concludes with an ominous line, "Your conduct will be closely monitored." Letter from Robert P. Ducatman, supra note 57. The letter was also sent to the domain registrar and hosting service, GoDaddy.com. Id. Although GoDaddy.com has no legal obligation to take down the domain name, Jones Day may have hoped that GoDaddy.com believed it needed to take down the website to comply with the safe harbor for internet service providers under section 230 of the Communications Decency Act. See Immunity for Online Publishers Under the Communications Decency Act, Digital MEDia Law PROJEGT, http://www.dmlp.org/legal-guide/immunity-onlinepublishers-under-communications-decency-act (last visited Mar. 9, 2015).

147. Model Code of Prof'L Responsibility Canon 1 (2013).

148. Deborah L. Rhode, Professional Responsibility: Ethics by the Pervasive METHOD 41 (2d ed. 1998).

149. See State Adoption of the ABA Model Rules of Professional Conduct, AM. BAR Ass'N, 
the Model Rules to policing cease-and-desist letters adequately reflects state ethics rules. These rules govern all aspects of an attorney's professional conduct, covering behavior in interacting with a client, with the court, as well as with non-client parties. If a lawyer sends a cease-and-desist letter, Model Rules 3.1 and 4.4 should be implicated because both rules involve attorney interactions with a non-client. 150 However, even if attorneys followed both rules, concerning ambiguities and gaps in regulation still exist.

\section{Model Rules 3.1 and 4.4 Are Insufficient Policing Mechanisms}

\section{a. Model Rule 3.1 Meritorious Glaim and Contentions}

Model Rule 3.1 states, "A lawyer shall not bring or defend a proceeding, or assert or controvert an issue therein, unless there is a basis in law and fact for doing so that is not frivolous, which includes a good faith argument for an extension, modification or reversal of existing law." 151 This rule could be interpreted to regulate cease-and-desist letters that contain extremely weak or meritless claims. If all attorneys adhered to this rule there would never be frivolous claims or lawsuits, but in reality, there is a widespread understanding that the rules of professional conduct do not effectively

http://www.americanbar.org/groups/professional_responsibility/publications/model_rules_of_p rofessional_conduct/alpha_list_state_adopting_model_rules.html (last visited Mar. 9, 2015). For the Model Rules themselves, see Model Rules of Professional Conduct: Table of Contents, AM. BAR Ass'N, http://www.americanbar.org/groups/professional_responsibility/publications/model_rules_of_p rofessional_conduct/model_rules_of_professional_conduct_table_of_contents.html (last visited Mar. 9, 2015).

150. See Model Rules of Prof'l Conduct r. 3.1 (2013); Model Rules of Prof'L CONDUCT r. 4.4 (2013). There are a number of other Model Rules that could potentially also govern an attorney's conduct in sending a cease-and-desist letter. For example, Paragraph 9 of the Preamble, Model Rule 3.4 titled Fairness to Opposing Party and Counsel, and Model Rule 4.1 titled Truthfulness in Statements to Others. Paragraph 9 of the Preamble includes in a lawyer's responsibility the duty to zealously represent one's client but also maintain "a professional, courteous and civil attitude toward all persons involved in the legal system." MODEL RULES OF PROF’L CONDUCT Preamble, 99 (2013). However, an in-depth discussion of all of the Model Rules (including the Preamble) is outside the scope of this Article. Instead, this Article will briefly analyze Model Rules 3.1 and 4.4, highlight the main problems with each rule, and discuss the shortcomings with attorney ethical rules overall as an effective policing mechanism for abusive cease-and-desist letters.

Some states, like California, have additional rules that implicate communications between attorneys and non-clients. See CAL. Rules Of Prof'L CONDuct r. 5-100(a) (2013) (prohibiting California attorneys from threatening criminal, administrative, or disciplinary charges to obtain an advantage in a civil dispute). Although Rule 5-100 applies to pre-litigation behavior, the rule does not cover abusive cease-and-desist letters that threaten civil litigation proceedings, as the rule only prohibits "criminal, administrative, or disciplinary charges." Id.

151. Model Rules of Prof’L Conduct r. 3.1 (2013). 
prevent attorneys from bringing meritless claims.152 Due to this, there are a number of other mechanisms that attempt to regulate attorney and litigant behavior, such as various provisions in the Federal Rules of Civil Procedure, including Rule 11, which penalizes attorneys and litigants for bringing frivolous lawsuits. 153 Additionally, Model Rule 3.1 does not prohibit sending an abusive cease-and-desist letter if it contains some legally meritorious claims. 154 As such, there are other concerns with abusive cease-and-desist letters, for example, utilizing unnecessary legalese or demanding a settlement within a short timeframe, which the Model Rules do not address.

\section{b. Model Rule 4.4 Respect for Rights of Third Persons}

The title of Model Rule 4.4, "Respect For Rights Of Third Persons,"155 would seem to closely address the concern of preventing abusive cease-anddesist letters. The text of Model Rule 4.4(a) states, "In representing a client, a lawyer shall not use means that have no substantial purpose other than to embarrass, delay, or burden a third person, or use methods of obtaining evidence that violate the legal rights of such a person."156 However, the problem with abusive letters is that their substantial purpose is to stop the infringing actions through coercion, with the threats of embarrassment as a means to obtain the desired settlement. Furthermore, two of the three comments to Model Rule 4.4 appear to focus the rule on the gathering of evidence; 157 therefore, the meaning of the term "burden" could be interpreted as meaning burdensome discovery requests, rather than sending abusive letters.

\section{Additional Concerns: Partisanship, Enforcement and Coverage}

Notwithstanding the identified gaps in each of the Model Rules, even if the rules could theoretically prevent almost all instances of abusive letters sent by attorneys, there are at least three additional concerns that prevent the Model Rules from being entirely effective: partisanship, enforcement, and coverage.

152. See generally Alexander A. Reinert, Screening Out Innovation: The Merits of Meritless Litigation, 89 IND. L.J. 1191 (2014) (discussing multiple instances where attorneys filed meritless claims).

153. See FeD. R. Giv. P. 11. See also infra Part III.B.2.

154. See Model Rules of Prof'L Conduct r. 3.1 (2013).

155. Model Rules of Prof’L CONDUCT r. 4.4 (2013).

156. Id.

157. Id. r. 4.4 cmts. 2-3. 


\section{a. Partisanship}

The first concern is with an attorney's ability to identify violations of the ethical rules. Professor Andrew Perlman's recent article on "partisanship," or the assumption that lawyers are capable of being affiliated with one side of the matter while remaining sufficiently objective about their own conduct, persuasively shows that an attorney's objective self-analysis as to whether she is following the ethical rules is distorted.158 For example, where an attorney discovers documents that would be extremely detrimental to her client's case, that attorney may not disclose those documents and further, may not believe she has crossed the ethical line. Professor Perlman's article suggests that attorneys may believe that they are following the rules, but in fact are not, due to a lack of objectivity. 159 In the above example, the attorney may believe that she is acting as a "zealous" and ethical advocate due to her lack of objectivity. The concern with partisanship is that attorney ethical rules are mostly enforced through self-regulation. This means attorneys themselves are in charge of deciding when they are following the rules and will have a difficult time determining whether they are complying in situations where the legal standard (e.g., the meaning of a "meritless" cease-and-desist letter) is unclear. Additionally, attorneys have a duty to report ethical infractions of other attorneys.160 The threat of being reported is assumed to have a deterrent effect and limit unethical practices.161 But Professor Perlman's article casts serious doubt on this assumption, as unethical conduct is likely to go undetected. 162

\section{b. Enforcement}

The second concern is enforcement of the rules because enforcement is

158. See Andrew M. Perlman, A Behavioral Theory of Legal Ethics, 90 IND. L.J. (forthcoming 2015) (manuscript at 3).

159. Id.

160. MODEL RULES OF PROF'L CONDUCT r. 8.3(a) (2013) (“A lawyer who knows that another lawyer has committed a violation of the Rules of Professional Conduct that raises a substantial question as to that lawyer's honesty, trustworthiness or fitness as a lawyer in other respects, shall inform the appropriate professional authority.").

161. See generally Christine E. Parker, Robert Eli Rosen \& Vibeke Lehmann Nielsen, The Two Faces of Laweyers: Professional Ethics and Business Compliance with Regulation, 22 GEO. J. LEGAL ETHICS 201 (2009) (conducting empirical study into the ethical and legal compliance of lawyers and their clients).

162. See Perlman, supra note 158, at 16-22 (providing examples of studies showing that biases tend to cloud attorney's recognition of unethical conduct). 
primarily through self-regulation. 163 The implications of partisanship are that another attorney receiving an abusive cease-and-desist letter may not recognize the letter as abusive. 164 Notwithstanding partisanship, due to the characteristics of small businesses and individuals, it is unlikely that this population would have access to legal resources to assist them in identifying abusive behavior. Additionally, even where abusive behavior is identified by low-resourced entities, knowledge of how and where to report attorney conduct is confusing. State bar associations do conduct a certain amount of outreach education to local communities about attorney ethical behavior and attempt to ease the burden of reporting by maintaining online reporting systems. 165 However, additional assistance is needed.

\section{c. Coverage}

Finally, another concern of relying solely on the Model Rules to police abusive cease-and-desist letters is that they do not cover letters sent by nonattorneys. Although attorneys send the majority of cease-and-desist letters on behalf of their clients, there are certain instances when non-attorneys send letters. For example, the Chairman of Eastern Point Trust Company, a nondepository trust company, sent a cease-and-desist letter to Mr. Money Mustache, a financial advice blogger, alleging tortious business interference, conversion, trade disparagement, defamation, trademark, and copyright violations made by a post on its website. 166 The contents of the letter are abusive because it threatens to pursue litigation with an extremely weak legal claim if the demands are not met within five days. 167 The Model Rules would

163. But see MOdel Rules OF PROF’L CONDUCT r. 10 (2013).

164. See Perlman, supra note 158, at 31-32 (discussing the issue of "ethical fading," which are blind spots, particularly in light of the structures of modern law firms).

165. See, e.g., Lawyer Regulation, CAL. STATE BAR, http://calbar.ca.gov/Attorneys /LawyerRegulation.aspx (last visited Mar. 9, 2015); Resolving Conflict With a New York Attorney: A Guide to Attorney Disciplinary Procedures in New York State, N.Y. STATE BAR Ass'N, http://www.nysba.org /CustomTemplates/SecondaryStandard.aspx?id=26561 (last visited Mar. 9, 2015); Client-Attorney Assistance Program (CAAP), TEX. STATE BAR, http://www.texasbar.com/Content/NavigationMenu /ForThePublic/ProblemswithanAttorney/CAAP/default.htm (last visited Mar. 9, 2015); File a Complaint Against a Lawyer, WASH. STATE BAR ASS'N, http://www.wsba.org/Licensing-andLawyer-Conduct/Discipline/File-a-Complaint-Against-a-Lawyer (last visited Mar. 9, 2015).

166. Letter from Glen Armand, Chairman, Eastern Point Trust Co., to MrMoneyMustache.com (Feb. 6, 2014), available at http://www.mrmoneymustache.com/wpcontent/uploads/2014/03/kisstrust_first_bullshit_letter.jpg.

167. Id.; see also Tim Cushing, Company Fires Off Legal Threats To Site Owner Over Third-Party Forum Post; Self-Inflicted Damage Ensues, TECHDIRT (Mar. 14, 2014), https://www.techdirt.com/articles /20140313/07405826562/company-fires-off-legal-threats-to-site-owner-over-third-party-forumpost-self-inflicted-damage-ensues.shtml (discussing the tenuousness of the letter's claims). 
not cover this letter because the Chairman is not a licensed attorney. ${ }^{168}$ Additionally, it is popular for large intellectual property rights holders to have brand managers, typically non-attorneys, manage the enforcement of their trademark portfolio. 169 While brand managers may work in concert with an attorney to draft a standard cease-and-desist letter, a non-attorney brand manager is not bound by any ethical rules. Thus, even if Model Rules 3.1 and 4.4 were effective in policing abusive cease-and-desist letters sent by attorneys, these rules would not cover all abusive letters.

\section{B. Judicial Protection Against Abusive Litigants}

The sender of an abusive cease-and-desist letter is similar to an abusive litigant in that the sender is attempting to utilize the legal system to coerce the target into yielding to its demands. As such, two forms of protection against abusive litigants, the potential for declaratory judgment actions and sanctions under the Federal Rules of Civil Procedure, could apply to situations of abusive cease-and-desist letters.

\section{Declaratory Judgment Actions}

A declaratory judgment action allows the recipient of a cease-and-desist letter to file a lawsuit against the sender seeking to resolve any legal uncertainty. ${ }^{170}$ This allows targets to potentially resolve the controversy raised by cease-and-desist letters faster because they do not have to wait to see whether or not the sender brings the threatened lawsuit. ${ }^{171}$ Depending on the type of legal violation stated in the cease-and-desist letter, this procedure is a valuable way to "clear the air" and move forward with one's

168. See Cushing, supra note 167 (reporting that Glen Armand is not an attorney).

169. Leah Chan Grinvald, Resolving the IP Disconnect for Small Businesses, 95 MARQ. L. REV. 1491,1529 (2012).

170. See 28 U.S.C. $§ 2201$ (a) (2012) ("In a case of actual controversy within its jurisdiction ... any court of the United States . . may declare the rights and other legal relations of any interested party seeking such declaration, whether or not further relief is or could be sought.").

171. See Megan M. La Belle, Patent Litigation, Personal Furisdiction, and the Public Good, 18 GeO. MASON L. REV. 43, 45 (2010) (stating that declaratory relief in patent cases are effective because the alleged infringer chooses the forum and controls the timing of suit). See also R. Scott Weide, Patent Enforcement Deterrence: Liberal Assertions of Personal Jurisdiction in Declaratory Fudgment Actions, 65 UMKC L. REV. 177, 177 (1996) ("In many instances, the filing of a declaratory judgment action gives the alleged infringer a significant strategic advantage over the patent owner."); Homer Yanghsien Hsu, Neutralizing Actual Controversy: How Patent Holders Can Reduce the Risk of Declaratory Fudgment in Patent Disputes, 6 WASH. J.L. TECH. \& ARTS 93, 96 (2010) ("The advantages of declaratory judgments for alleged patent infringers are many."). 
business or life. ${ }^{172}$ Due to this ability, as well as the central role intellectual property plays in some businesses' products, declaratory judgment actions are frequently sought in patent disputes.173

However, the problem with declaratory judgment actions is that it is still a judicial procedure that comes with the commensurate time and expense of litigation.174 This means that the characteristics of small businesses and individuals will continue to hinder this group of disputants with an inability to follow through with litigation, and it is unlikely that this population would be able to bring a declaratory judgment action. Unlike in a regular lawsuit where a plaintiff may be able to find a contingency-fee attorney, it is unlikely that a plaintiff's attorney firm would be willing to take a target's declaratory judgment case because the target is the one that is claimed to be in the wrong. Further, even if a small business or individual has business insurance that covers defending an action, the insurance policy would likely require the small business or individual to wait until the plaintiff initiates a legal action in order to pay for the defense. 175

172. See Chester S. Chuang, Unjust Patents \& Bargaining Breakdown: When is Declaratory Relief Needed?, 64 SMU L. REV. 895, 899-900 (2011) (noting importance of declaratory relief to potential infringers because of substantial damage awards); Tejas N. Narechania, An Offensive Weapon?: An Empirical Analysis of the "Sword" of State Sovereign Immunity in State-Owned Patents, 110 COLUM. L. REV. 1574, 1590 (2010) ("[D] eclaratory judgment actions serve an important role in the intellectual property system ....") (internal quotations omitted); Marta R. Vanegas, You Infringed My Patent, Now Wait Until I Sue You: The Federal Circuit's Decision in Avocent Huntsville Corp. v. Aten International Co., 92 J. PAT. \& TRADEMARK OfF. SOG'Y 371, 384 (2010) ("Congress enacted the Declaratory Judgment Act to eliminate uncertainty in situations where one of the parties threatens to sue but does not proceed. . . . Congress was especially mindful of the problems presented in patent, trademark, and copyright infringement cases.").

173. Jeanne C. Fromer, Patentography, 85 N.Y.U. L. REV. 1444, 1464 (2010) (stating that in all jurisdictions outside of the Eastern District of Texas declaratory judgments accounted for $15.49 \%$ of patent suits filed in 2005). See also Kimberly A. Moore, Forum Shopping in Patent Cases: Does Geographic Choice Affect Innovation?, 79 N.C. L. REV. 889, 921 (2001) (stating that declaratory judgments brought by the infringer accounted for $14 \%$ of all tried cases in the dataset). Additionally Professor Megan La Belle's research in the area shows a close link between the Declaratory Judgment Act and patent litigation. Megan M. La Belle, Patent Law as Public Law, 20 GeO. Mason L. Rev. 41, 60-61 (2012).

174. See Donald L. Doernberg \& Michael B. Mushlin, The Trojan Horse: How the Declaratory Judgment Act Created a Cause of Action and Expanded Federal Furisdiction While the Supreme Court Wasn't Looking, 36 UCLA L. REV. 529, 531-32 (1989) ("A declaratory judgment action is designed to permit a party to obtain an 'authoritative judicial statement of the legal relationships,' regardless of whether a coercive legal or equitable remedy is sought.") (quoting Frank M. Gilliland, Jr., Note, Federal Question Furisdiction of Federal Courts and the Declaratory Fudgment Act, 4 VAND. L. REV. 827, 830 (1951)).

175. Eliot M. Harris, The Duty to Defend: What Insurers, Insureds and Their Counsel Need to Know When Faced with a Liability Coverage Dispute, AM. BAR Ass'N, http://www.americanbar.org /groups/young_lawyers/publications/the_101_201_practice_series/duty.html (last visited Mar. 9, 2015). Most business insurance policies contain a "duty to defend," which protects the insurance 


\section{Federal Rules of Givil Procedure}

A number of Rules of Civil Procedure at both the state and federal level could potentially regulate abusive cease-and-desist letters. ${ }^{176}$ For example, Rule 11 of the Federal Rules of Civil Procedure intends to prevent attorneys and their clients from bringing frivolous lawsuits. ${ }^{177}$ Where there is a violation of Rule 11, either the court or a litigant may bring a motion to sanction another litigant or their attorney. ${ }^{178}$ However, the problem with relying on Rules of Civil Procedure to police abusive cease-and-desist letters is that courts cannot impose sanctions until the litigation reaches the judicial system. For example, Rule 11 only authorizes sanctions against attorneys or their clients for representations made in court filings. ${ }^{179}$ As mentioned earlier, the cease-and-desist letter process is mainly extra-judicial, and therefore, a judge would never be involved to sanction the sender of an abusive ceaseand-desist letter. Additionally, even where litigation arises based on an abusive cease-and-desist letter, it is likely that an abusive letter would still not be subjected to regulation by Rule 11, as it is not a court filing, but rather a private communication between the parties sent prior to litigation. ${ }^{180}$

\section{State Anti-Patent Troll Legislation}

The problems concerning abusive cease-and-desist letters and abusive litigation in the patent area received national attention a few years ago with the increase in what has been termed as "patent troll" litigation. ${ }^{181}$ The term "patent troll" refers to the practice of some business entities of purchasing patents without the intention of practicing the invention contained within the

policyholder in cases where a lawsuit is filed against her, not the other way around. Id.

176. See, e.g., Cal. Civ. Proc. Code $\$ 128.5$ (West 2015); N.Y. COMP. Codes R. \& REGS. tit. 22, § 130-1.1 (2015); WASH. REV. CODE ANN. § 7.70.160 (West 2015).

177. See FED. R. GIV. P. 11.

178. FED. R. CIV. P. 11(c). However, only attorneys can be sanctioned for violations of Rule 11 (b)(2), which requires an attorney certifies that the "claims, defenses, and other legal contentions are warranted by existing law or by a nonfrivolous argument for extending, modifying, or reversing existing law or for establishing new law." FED. R. CIV. P. 11(b)(2); see also FED. R. CIV. P. 1 1(c)(5)(A).

179. FED. R. CIV. P. 11.

180. See id. Sometimes abusive cease-and-desist letters are entered into evidence in a civil litigation, but oftentimes it is simply to buttress a claim of notice or to fight against personal jurisdiction in a declaratory judgment action. See Athletic Training Innovations, LLC v. L.A. Gear, Inc., No. 10-1524, 2010 WL 4103309, at*5 (E.D. La. Oct. 18, 2010) (holding that an abusive ceaseand-desist letter, when sent to plaintiff and its customers, supports a finding of personal jurisdiction over defendant). Additionally, even where senders of abusive cease-and-desist letters are subject to judicial scrutiny, the likelihood of a judge issuing sanctions is fairly slim. Manta, supra note 7, at 860 .

181. See Colleen V. Chien, Reforming Software Patents, 50 Hous. L. REV. 325, 327-28 (2012). 
patent (also referred to as non-practicing entities or patent assertion entities). 182 Instead, the reason for purchasing the patent is to simply enforce its rights against unauthorized users to extract licensing fees.183 Although patent law implicitly authorizes entities having no intention to practice the invention to acquire patents, this form of patent enforcement became problematic when patent trolls began filing multiple lawsuits against targets, clogging up the court dockets. 184 However, it was not until patent trolls began to target small businesses and individuals that the problem reached executive and legislative attention. 185

A number of different bills were introduced in Congress to combat the problem of patent trolls, but all have been stalled. ${ }^{186}$ In response to the congressional inaction, a wave of "anti-patent troll" legislation began to take hold at the state level in 2013. As of the date of this Article, there are approximately twenty-two states with this type of legislation. 187 Each state's legislation differs slightly, but at the core of each statute is a prohibition on

182. Id.; see also Colleen Chien, Presentation to the DOJ/FTC Hearing of PAEs: Patent Assertion Entities (Dec. 10, 2012), available at http://papers.ssrn.com/sol3 /papers.cfm?abstract_id=2187314. Not all non-practicing entities (NPEs) purchase their patent portfolio. Some NPEs, like universities, have organic patent portfolios from their research departments. Mark A. Lemley, Are Universities Patent Trolls?, 18 FordHAM InTELL. PROP. MediA \& ENT. L.J. 611, 612-14 (2008) (answering the title's question in the negative, and terming universities as non-practicing entities).

183. See Mark A. Lemley \& A. Douglas Melamed, Missing the Forest for the Trolls, 113 CoLuM. L. REV. 2117, 2126-27 (2013) (describing these entities as "patent aggregators").

184. See Chien, supra note 182 (finding that in 2012, patent assertion entities filed $61 \%$ of all patent infringement lawsuits).

185. See White House RePORT, supra note 12, at 1 (noting that small businesses are frequent targets of patent troll demand letters); Colleen Chien, Startups and Patent Trolls, 17 Stan. Tech. L. REV. 461, 464-65 (2014) (finding that 40\% of small businesses had been targets of patent troll ceaseand-desist letters for using technology provided by another party); Catching $U_{p}$ on . . Innovatio IP Ventures, LLC's Litigation Activities, Essential PATENT Blog (Jan. 3, 2013), http://essentialpatentblog.com/2013/01/catching-up-on-innovation-ip-ventures-llcs-litigationactivities/ (reporting on Innovatio's use of Broadcom's patents to sue businesses such as restaurants, coffee shops, hotels, and grocery stores that use wireless internet).

186. See Patent Progress's Guide to Federal Patent Reform Legislation, Patent Progress, http://www.patentprogress.org/patent-progress-legislation-guides/patent-progresss-guide-patentreform-legislation/ (last visited Mar. 10, 2015); Joe Mullin, Anti-Patent-Troll Bill Stalls in Senate, But Reformers Remain Hopeful, ARS TECHNICA (Apr. 10, 2104), http://arstechnica.com/techpolicy/2014/04/anti-patent-troll-bill-stalls-in-senate-but-reformers-remain-hopeful/. However, none of the bills attempt to address letters sent by patent trolls, just litigation behavior. See, e.g., Innovation Act, H.R. 9, 114th Cong. § 299A (2015) (proposing to add a new section to the Patent Act, 35 U.S.C. $§ 299 \mathrm{~A}$, that recognizes the abusiveness of demand letters, but does not sanction the letters themselves rather the litigation stemming from such letters).

187. See Patent Progress's Guide to State Patent Legislation, supra note 21 (providing an interactive map of states with different stages of anti-patent troll bills). 
sending a bad faith assertion of patent infringement through cease-and-desist letters. 188 Determining a "bad faith assertion" is factor-based, and each statute contains similar factors, such as lack of disclosure of the patent in the letter (or failure to provide the information once requested), and demands for payment. 189 While these statutes are a step in the right direction, their applicability is limited to bad faith claims of patent infringement. Therefore, state laws only provide limited coverage, and would not prohibit abusive cease-and-desist letters containing claims of other types of violations. Additionally, the text of the statutes contains limitations. ${ }^{190}$ For example, some statutes, like those in Wisconsin, focus on the disclosures contained in the cease-and-desist letter, rather than on the abusiveness of the demands. ${ }^{191}$ This means that savvy senders of abusive cease-and-desist letters can easily escape any legal consequences by complying with the statute's disclosure provisions.

\section{Consumer Protection Law}

A final potential source of regulation for abusive cease-and-desist letters is federal and state consumer protection law because sending abusive ceaseand-desist letters can constitute an unfair and/or deceptive trade practice. At the federal level, the Federal Trade Commission (FTC) has the authority under the Federal Trade Commission Act to bring enforcement actions against entities conducting unfair and/or deceptive trade practices. 192 At the state level, each state attorneys general office enforces the state's version of

188. See, e.g., IDAHO CODE ANN. § 48-1703 (West 2014). The state statutes refer to the ceaseand-desist letter as a "demand" letter. Some of the statutes provide a definition of a "demand" letter to include a "letter, email or other communication asserting or claiming that the target has engaged in patent infringement." See, e.g., id. § 48-1702.

189. See, e.g., UTAH CODE ANN. § 78B-6-1903 (West 2014). In addition, many states include discretion for the court to consider other factors when determining the bad faith nature of the patent infringement claim. See id. But see WIS. STAT. ANN. § 100.197(2) (West 2014) ("A patent notification shall contain all of the following .... If a patent notification lacks any of the information required ... the target may notify the person who made the patent notification that the patent notification is incomplete.") (emphasis added).

190. A systemic review of the state laws are beyond the scope of this Article. For coverage of all forms of patent reforms, see ANDREW S. BALUCH, PATENT REFORM 2014: A COMPREHENSIVE Guide to Current Patent Reform Developments in Congress, the Executive BRANCH, THE COURTS AND THE STATES (Mar. 24, 2014), available at http://www.foley.com/files/Publication/496991 lf-42ea-4566-90c9-3fa620d12f91/Presentation /PublicationAttachment/6ec9626b-2190-4a1 1-9d51-425adec351f0/PatentReform2014.pdf.

191. WIS. STAT. ANN. § 100.197(2) (West 2014).

192. 15 U.S.C. $\S 45$ (2012). 
the "unfair and deceptive practices" act. 193 Some abusive cease-and-desist letters come under the ambit of consumer protection laws, particularly where they contain deceptive statements or false threats of litigation.194 In fact, recent enforcement actions taken by the FTC and the Attorneys General of New York, Nebraska, and Vermont, against the "scanner troll," $195 \mathrm{MPHJ}$ Technology Investments, LLC, shows the ability of consumer protection laws to regulate the senders of abusive cease-and-desist letters. 196

However, a severe limitation of utilizing consumer protection laws as the sole means to police abusive cease-and-desist letters is that few letters will meet the criteria for enforcement efforts by the FTC or a state attorney general. The reason the FTC and a state attorney general could take action against MPHJ Technology was because of the extreme number of small businesses it threatened, and the deceptiveness it used in attempting to coerce license fees. 197 But other well-known patent trolls, such as Innovatio, have escaped similar FTC and state attorneys general enforcement actions despite undertaking actions similar to MPHJ Technology, but not in the same deceptive manner. 198 Therefore, where senders of abusive cease-and-desist letters sufficiently disclose their claims and do not target thousands of small

193. See Garolyn L. Garter, Consumer Protection in the States: A 50-State REPORT ON UNFAIR AND DECEPTIVE ACTS AND PRACTICES STATUTES 6 (Feb. 2009), available at https://www.nclc.org/images/pdf/udap/report_50_states.pdf.

194. Prepared Statement of the Fed. Trade Comm'n on Discussion Draft of Patent Demand Letter Legislation Before the Subcomm. on Commerce, Mfg., \& Trade of the H. Comm. on Energy \& Commerce 3-4 (May 22, 2014) (statement of Lois Greisman, Assoc. Dir. Div. Mktg. Practices, Fed. Trade Comm'n) [hereinafter Statement of Lois Greisman].

195. See Samuels, supra note 38 (describing MPHJ technology as the "scanner troll").

196. See Vermont v. MPHJ Tech. Investments, LLC, No. 2:13-GV-170, 2014 WL 1494009 (D. Vt. Apr. 15, 2014); MPHJ Tech. Investments, LLG v. Fed. Trade Comm'n, No. 6:14-cv-11, 2014 WL 189831 (W.D. Tex. Jan. 13, 2014) (initiating a lawsuit against FTC for its investigations of MPHJ); Activision TV, Inc. v. Pinnacle Bancorp, Inc., No. 8:13GV215, 2014 WL 197808 (D. Neb. Jan. 14, 2014); N.Y. Press Release, supra note 13.

197. MPHJ utilized a dizzying array of shell companies to represent itself, leaving the target unable to speak to a person about the claims contained in the abusive letters. See MPHF Tech. Investments, LLC, 2014 WL 1494009, at*1-2 (describing the process by which MPHJ operated).

198. Innovatio, or the "wifi patent troll," sent numerous abusive cease-and-desist letters to small businesses for infringement of its wifi patents. Daniel Nazer, Infamous Wi-Fi Patent Troll Settles for Peanuts, TROLLING EFFECTS (Feb. 7, 2014), https://trollingeffects.org/blog/infamous-wi-fipatent-troll-settles-peanuts. Attempting to protect its customers, Cisco and a number of other equipment manufacturers brought an action against Innovatio alleging RICO (fraud and racketeering) conspiracy. In re Innovatio IP Ventures, LLC, Patent Litig., No. 1:1 1-cv-09308, 2012 WL 8500139, 1 (N.D. Ill. Oct. 1, 2012). Cisco's RICO claims were dismissed and it eventually settled with Innovatio for 3.2 cents per user. See Thomas F. Cotter, Judge Holderman's RAND Ruling in In re Innovatio IP Ventures, LLC Patent Litigation, COMPARATIVE PATENT REMEDIES (Oct. 3, 2013), http://comparativepatentremedies.blogspot.com/2013/10/judge-holdermans-randruling-in-in-re.html. 
businesses in any one particular state, the senders will likely escape legal liability.

In conclusion, there does not appear to be any one regulatory mechanism that fits the concerns posed by abusive cease-and-desist letters. The Model Rules potentially come the closest, but gaps in protection still exist within the rules, and they also do not cover all senders of abusive ceaseand-desist letters. Additionally, without a serious threat of enforcement, the rules themselves cannot be effective. Moreover, although the recently enacted state anti-patent troll laws are a step in the right direction, they are too narrow in scope as they specifically attempt to cover abusive patent ceaseand-desist letters. Further, actions taken by the FTC and state attorneys general against MPHJ Technology under consumer protection laws are another potential avenue for regulation, but currently the actions appear to be limited to extreme situations where the sender conducts a deceptive and widespread enforcement campaign. Finally, a more theoretical concern with each of the various forms of potential regulation is that they do not address any of the characteristics of small businesses and individuals that contribute to the coercive settlement process. Therefore, mechanisms need to be implemented that could better assist with policing abusive cease-and-desist letters that specifically target the characteristics of this vulnerable population.

\section{Proposals to Police Abusive Cease-and-Desist Letters}

This Article's proposals attempt to attack the problem of abusive ceaseand-desist letters from both sides of the dispute, sender and target, with the goal of creating a non-coercive settlement environment for small businesses and individuals. First, on the sender side, the proposals attempt to reduce the incidences of abusive cease-and-desist letters by altering the incentives that create an environment ripe for abusive letters. Second, on the target side, the proposals aim to provide mechanisms that assist small businesses and individuals in overcoming the characteristics that leads to a coercive settlement process in asymmetrical disputes. While none of the proposals individually are a panacea for the problems of abusive cease-and-desist letters, they are an important first step in encouraging the serious and noncoercive enforcement of legal rights.

\section{A. Legislative Action}

The first proposal is for Congress and/or states to provide a new cause of action for "abusive threats" similar in nature to the previously discussed state anti-patent troll laws, as well as borrowing some procedural advantages 
from state anti-SLAPP laws. ${ }^{199}$ Before discussing the elements of this new cause of action, it is important to note the objectives of this proposal and its limitations. The objectives of this proposal are to reduce the incidences of abusive cease-and-desist letters and assist small businesses and individuals. The goal is not to hamper good faith efforts to enforce valid legal rights, but rather, to provide a non-coercive and more equalized platform for parties of all sizes to enforce their rights and negotiate a fair settlement. Providing a new cause of action for abusive threats would accomplish this goal in two ways.

First, the cause of action attacks the incentives that rights holders have to send abusive cease-and-desist letters. As discussed in Part II, the major incentives for sending abusive cease-and-desist letters include a lack of legal consequences for the action, and the letter's effectiveness in obtaining the desired outcome. Without any real possibility of legal consequences, rights holders are incentivized to send abusive letters because they are low in cost. It is more rational for a sender to first send an abusive cease-and-desist letter, and then subsequently analyze whether actually pursuing litigation would be advantageous. Implementing a cause of action for abusive threats that carries serious financial risks for the sender of an abusive letter creates the possibility for greater accountability and would likely result in rights holders recalibrating their enforcement tactics.

Second, the anti-abusive threats law would attack two of the three characteristics that cripple small businesses and individuals in an abusive cease-and-desist letter process: the inability to information-gather and susceptibility to inducement. This would be done by providing small businesses and individuals the ability to recover damages, attorneys' fees, and legal costs. These remedies would allow small businesses or individuals to more easily retain attorneys on a contingency fee basis. 200 With an ability to retain an attorney, a low-resourced target of an abusive letter would be able to information-gather because the attorney would advise the small business or individual on the strength of the claims contained within the letter, as well as the target's relative rights. While an attorney may still advise the lowresourced target that a settlement is preferable,201 the decision would be

199. See supra Part III.C. See generally Curtin, supra note 96.

200. Contingency fee arrangements assist low-resourced entities in obtaining legal representation. Peter Karsten, Enabling the Poor to Have Their Day in Court: The Sanctioning of Contingency Fee Contracts, A History to 1940, 47 DePAul L. REV. 231, 243 (1998).

201. For example, when Matt Nadau of RockArt Brewery (a small brewery in Vermont) faced a potential legal battle with Hansen Beverages, his lawyer explained the risks of fighting back against a large corporation and ultimately advised him to settle. See Matt vs. The Monster 2011 Bronze Telly, 
informed, rather than one made through coercion. Additionally, an attorney could curb some of the emotional inducement frequently experienced by low-resourced targets through counseling and education.

However, this cause of action would not be a panacea to the problems associated with the abusive cease-and-desist letter. For example, the new law would not attack the systemic problem of expensive litigation. Similarly, the new law would not cover the general over-enforcement of legal rights by Americans and, in particular, by U.S. intellectual property rights holders.202 Instead, this new law will provide modest and incremental assistance to lowresourced targets.

Although this Article does not suggest specific language for the proposed cause of action, it does take the position that developing a cause of action should be enacted statutorily, rather than solely through the courts. The need for uniformity and certainty in the law support this position. In recent years, judges have become more "textualist" with respect to interpreting statutes and defenses to violations, particularly with respect to federal intellectual property laws. ${ }^{203}$ If a cause of action or defense is not explicitly stated within the statute, textualist judges would likely rule against the claimant. ${ }^{204}$ Further, certainty that a court accepts suits brought by targets of abusive cease-anddesist letters would assist in making contingency fee attorneys feel more comfortable that their client would not face an uphill battle.

This Article broadly envisions three elements to bring an "anti-abusive threats" cause of action: (1) there is an allegation of a legal rights violation; (2) that is abusive; (3) made to a specific target. All of these elements would need to be met within the first cease-and-desist letter sent to the target in order for the letter to be actionable. This limitation should assist in protecting good faith enforcers of legal rights who encounter targets that attempt to provoke abuse. 205 However, standing to bring this cause of action should not

\footnotetext{
GREEN RIVER PICTURES, http://www.grpny.com/index.php/about-us /awards?videoid=41738861 (last visited Mar. 15, 2015).

202. Over-enforcement is a problem of private enforcement of legal rights by intellectual property rights holders, and is the topic of separate research by this Article's author, along with coauthors Eric Goldman and Deborah Gerhardt.

203. See Michael Grynberg, Things Are Worse Than We Think: Trademark Defenses in a "Formalist" Age, 24 Berkeley TeCH. L.J. 897, 927 (2009).

204. See, e.g., ITG Ltd. v. Punchgini, Inc., 482 F.3d 135, 165 (2d Cir. 2007) (stating that despite a compelling policy argument, the court would not recognize the "famous marks doctrine" in trademark law because it was not explicitly written into federal trademark law).

205. For example, David Thorne, a comedian and author, provokes abusive behavior by publishing his emails and letters in books and on his website. See generally DAVID THORNE, THE INTERNET IS A PLAYGROUND: IRREVERENT CORRESPONDENCES OF AN EVIL ONLINE GENIUS
} 
only be limited to the recipients of the abusive letter, but by any person who is aggrieved by such a letter. 206

\section{Allegation of Legal Rights Violation}

One of the deficiencies identified in Part III.C with respect to the recently enacted anti-patent troll legislation was that the laws only dealt with bad faith claims of patent infringement. However, abusive letters claiming legal rights violations occur across all areas of the law. For example, a number of cases in California courts concerning abusive letters deal with the misuse of company funds and prior sexual conduct.207 Aside from the political and media attention that "patent trolls" have garnered, there does not appear to be a reason as to why other types of intellectual property rights or other legal rights are exempt from the requirement of good-faith enforcement. 208

\section{Abusive Letter}

Determining abusiveness is challenging, as is seen from the discussions

(2011); 27B/6, http://www.27bslash6.com/ (last visited Mar. 15, 2015). Mr. Thorne received a cease-and-desist letter from Penguin Books Ltd. (the publisher of his first book) for the artwork displaying a penguin with its finger raised printed on the cover of his second book. See Dennis Johnson, Penguin is Not Amused, Melville House (Mar. 26, 2012), http://www.mhpbooks.com /penguin-is-not-amused/. As can be seen from the series of emails and letters, Mr. Thorne is purposefully provocative. Penguin, 27b/6, http://www.27bslash6.com/covers.html (last visited Mar. 15, 2015).

206. This is similar to the United Kingdom's remedy for groundless threats of infringement proceedings. See, e.g., Patents Act, 1977, c. 37, § 70(1) (Eng.) ("Where a person . . . threatens another person with proceedings for any infringement of a patent, a person aggrieved by the threats (whether or not he is the person to whom the threats are made) may . . . bring proceedings in the court against the person making the threats."); Trade Marks Act, 1994, c. 26, § 21(1) (Eng.) ("Where a person threatens another with proceedings for infringement of a registered trade mark . . . any person aggrieved may bring proceedings for relief under this section."); Registered Designs Act, 1949, 12, 13 \& 14 Geo. 6, c. 88, § 26(1) (Eng.) ("Where any person ... threatens any other person with proceedings for infringement of the copyright in a registered design, any person aggrieved thereby may bring an action against him."); Copyright Designs and Patents Act, 1988, c. 48, § 253(1) (Eng.) ("Where a person threatens another person with proceedings for infringement of design right, a person aggrieved by the threats may bring an action against him.").

207. See, e.g., Malin v. Singer, 159 Cal. Rptr. 3d 292, 303 (Cal. Ct. App. 2013) (involving allegations of embezzlement); Flatley v. Mauro, 139 P.3d 2, 5 (Cal. 2006) (involving allegations of sexual misconduct).

208. Patent trolls have garnered national attention, whereas other abusers of legal rights have not, such as copyright trolls and trademark bullies. However, the harms caused by these other types of abusers are similar in nature to patent trolls. See Matthew Sag, Copyright Trolling, An Empirical Study, 100 IOWA L. REV. 1105, 1107 (2015). 
surrounding the abusive letters in California referenced above. ${ }^{209}$ Although multi-factor tests are often problematic, 210 this Article favors a non-exclusive factor approach in discerning abusiveness to give courts an appropriate amount of discretion. Additionally, the non-exclusive factor approach allows for changes in social norms that necessarily inform this type of analysis. The factors specified in Part I.B are examples of non-exclusive factors that could be adopted to determine when a cease-and-desist letter is abusive, but other factors may be relevant, depending on the type of legal claim asserted.211 Finally, only the first communication sent to the target would be examined for abusiveness. This limitation would safeguard against targets that attempt to utilize the new cause of action to goad the legal rights holder into sending an abusive letter. A number of well-resourced individuals enjoy provoking rights holders to see if they become abusive out of frustration. 212

\section{Made to a Target}

This last element is worded broadly in order to afford many different types of targets standing to sue an abusive sender. Senders can target a wide range of different entities other than the alleged violator, such as the alleged violator's customers, distribution network, or supply chain.213 At times, it may be more efficient or economical for a rights holder to threaten the supply chain or customers of an alleged violator, rather than the actual infringer.214 For example, the patent troll Innovatio, targeted the customers of Cisco and other router manufacturers with its cease-and-desist letters.215 Although

209. In Malin v. Singer, the California district court found that the attorney (Martin Singer) had sent an abusive letter, while the appellate court reversed. Malin v. Singer, No. BC466696, 2011 WL 6070271 (Cal. Super. Nov. 29, 2011), aff d in part, rev'd in part, 159 Cal. Rptr. 3d 292, 304 (Cal. Ct. App. 2013). In Flatley v. Mauro, the California courts held that the attorney's letter (sent by Mauro) was abusive and amounted to extortion as a matter of law. Flatley v. Mauro, 18 Cal. Rptr. 3d 472, 486 (Cal. Ct. App. 2004), aff'd, 139 P.3d 2, 24 (Cal. 2006). Commentators have been attempting to reconcile the two holdings. See Kennerly, supra note 135; Parker \& Yang, supra note 135.

210. See Barton Beebe, An Empirical Study of the Multifactor Tests for Trademark Infringement, 94 CALIF. L. ReV. 1581, 1614-15 (2006).

211. See supra Part I.B (listing inappropriate legalese or other harsh or insulting language, demands for quick settlement, demands for immediate payment fees, and weak or unreasonable claims of rights violations as potential factors to determine abusiveness).

212. See supra note 205.

213. See Grinvald, supra note 169, at 1526-31 (discussing effective enforcement frameworks for abusive rights holders).

214. See id.

215. See Catching Up on . . Innovatio IP Ventures, LLC's Litigation Activities, supra note 185. 
Cisco and other manufacturers brought a declaratory judgment action against Innovatio on behalf of its customers, 216 other entities may not be so proactive and they will likely need to give into the cease-and-desist letter.

\section{Procedural Elements}

In addition to the substantive elements, there are a number of procedural elements that need to be implemented that are crucial to assisting low-resourced targets. First, the burden of proof of whether the letter is abusive would be on the letter sender. Second, fast-track status would be given to such lawsuits filed by abusive letter targets, similar to the special motions to strike filed under anti-SLAPP laws.217 Finally, if a court found a letter abusive, it would award damages, attorneys' fees, and legal costs to the target. Each of these elements will be discussed in turn.

\section{a. Burden of Proof}

An important part of the anti-abusive threats cause of action would be having the burden on the sender of the letter to prove that the letter is not abusive. 218 One main reason for this requirement is that the party who bears the burden of proof in civil litigation also bears the costs of producing evidence needed to resolve the dispute. ${ }^{219}$ Letter senders, unlike targets, are in the best practical and economical position to provide evidence to prove the information contained in the letter, why it chose to send the letter to the target, and the reasoning behind the letter's settlement demand costs or timeframe. Since the sender wrote the letter, it presumably has easy access to all the evidence needed to satisfy its burden of proof. Thus, it is more costeffective for the sender to bear the burden, and it reduces the costs of bringing

216. In re Innovatio IP Ventures, LLC, Patent Litig., No. 1:11-cv-09308, 2012 WL 8500139, II 1 (N.D. Ill. Oct. 1, 2012); see also Mark Chandler, Innovatio Case: Victory for Cisco Customers Makes the Case for Patent Reform, Cisco BlOGS (Feb. 6, 2014, 9:48 AM), http://blogs.cisco.com/news /innovatio-case-victory-for-cisco-customers-makes-the-case-for-patent-reform.

217. See, e.g., CaL. Civ. Proc. CODE $§ 425.16$ (f) (West 2015) (requiring the court to schedule a hearing on an anti-SLAPP motion no more than thirty days after the service of the motion).

218. The burden of proof is an extremely important element of civil litigation, as who bears the burden oftentimes influences the outcome. Robert Belton, Burdens of Pleading and Proof in Discrimination Cases: Toward a Theory of Procedural Fustice, 34 VAND. L. REv. 1205, 1207 (1981) ("[T] he allocation of the burdens of proof during trial often has a significant effect on the outcome of a case and frequently may be dispositive.").

219. Roger B. Dworkin, Easy Cases, Bad Law, and Burdens of Proof, 25 VAND. L. REv. 1151, 1153 (1972) ("On each issue in a case some party must carry the burden of producing evidence or lose at the hands of the judge ...."). 
an anti-abusive threats cause of action for the target.220

\section{b. Fast-Track Status}

The length of litigation is a major contributor to its high cost. In 2012, the average hourly billing rate of an attorney employed by a private law firm in the United States was just under $\$ 400.221$ The longer a legal dispute runs, the higher the legal bills. Implementing a "fast-track" status for anti-abusive threats lawsuits would attempt to alleviate some of the costs associated with a lengthy court case. The known expense of litigation is one of the elements contributing to the increasing use of cease-and-desist letters for legal dispute resolution, and granting fast-track status could make going to the courts more attractive. Additionally, high litigation cost is a factor that places lowresourced targets in a coercive situation with well-resourced letter senders, and a knowingly quick judicial resolution would assist in overcoming the imbalance of power. Fast-track status would require a judge to schedule a hearing within a short timeframe after the defendant files a response.222 The notion of a fast-track status is not new: California's anti-SLAPP law requires a judge to schedule a hearing on the special motion within thirty days from service.223 Other commentators have also proposed similar types of mechanisms to expedite cases involving low-resourced entities, such as specialized small claims courts. 224

\section{c. Damages, Attorneys' Fees, and Legal Costs}

The type of remedies available for a cause of action plays an important strategic role in determining whether to bring a case.225 Although most causes

220. Bruce L. Hay \& Kathryn E. Spier, Burdens of Proof in Civil Litigation: An Economic Perspective, 26 J. LEGAL STUD. 413, 418-19 (1997) (providing an economic model demonstrating the optimal allocation of the burdens of proof in civil litigation)

221. See AIPLA 2013 REPORT, supra note 88, at 49.

222. See Steven P. Aggergaard, Three State-Based Defenses to Consider, FOR THE DeFEnSE, Apr. 2012, at 16, 18, available at http://www.bassford.com/newsevents-pressrelease-0412-spa.pdf.

223. Cal. Civ. Proc. Code $\S 425.16$ (f) (West 2015).

224. See, e.g., Eric Goldman, Department of Commerce Releases Worthless Report on Trademark Bullying, TECH. \& MKTG. LAW BLOG (Apr. 29, 2011), http://blog.ericgoldman.org/archives /2011/04/department_of_c.htm. Additionally, Professor Irina Manta has suggested that the USPTO act in an oversight capacity to assist in these disputes. Manta, supra note 7, at 866-71. Further, the USPTO requested comments as to whether the United States should establish a small claims proceeding for patent cases. See Request for Comments on a Patent Small Claims Proceeding in the United States, 77 Fed. Reg. 74,830 (Dec. 18, 2012).

225. For example, attorneys routinely strategize dispute resolution options based on the types of remedies involved. See Davis, supra note 122, at 14 ("[M] ost parties to lawsuits eventually decide 
of action allow a winning plaintiff to recoup damages, recovering attorneys' fees and legal costs is less typical.226 This is due to the "American rule" that requires each party in litigation to bear its own costs.227 However, certain types of litigation need incentives, or must at least be made easier to bring. Some courts recognize this need and allow for fee-shifting. ${ }^{228}$ Bringing an anti-abusive threats action should be encouraged, and implementing fee shifting provisions is critical because it may convince risk-adverse attorneys into taking on these cases.

The ability to bring a preemptory action against an abusive letter sender would assist in altering the incentives and overcoming some of the characteristics plaguing low-resourced targets. While the proposed antiabusive threats law would not directly attack the problem of the overenforcement of legal rights, with serious legal consequences at stake for overenforcing one's rights, it is likely that potential abusers would adopt a more appropriate approach to their legal rights enforcement efforts. However, due to the limitations of an anti-abusive threats law, additional measures are needed to fully address the problems facing low-resourced targets.

\section{B. Greater Involvement by Bar Associations}

In addition to the proposed anti-abusive threats law, greater involvement by state bar associations is needed in order to curb the incidences of abusive cease-and-desist letters. The ABA and state bar associations are in a good position to assist in this effort because attorneys write the majority of cease-and-desist letters. As previously discussed, the Model Rules of Professional Conduct do not explicitly cover the problem of abusive letters. ${ }^{229}$ Additionally, even if the rules explicitly prohibited abusive cease-and-desist letters, concerns with partisanship and the ability to objectively assess ethical violations would continue to exist.230 Although state

to pursue or to settle their claims based on a cost-benefit analysis.").

226. However, it is becoming more typical. See Rebecca Friedman, The Lodestar Ranger: Calculating Attorneys' Fee Awards in Perdue v. Kenny A., 5 Duke J. Const. L. \& Pub. Pol'y SidebAR 58, 62-63 n.31 (2009) (citing DOUGLAS LAYCOGK, MODERN AMERICAN REMEDIES: CASES AND MATERIALS 913 (3d ed. 2002)) ("More than 180 federal statutes and 4,000 state statutes authorize awards of attorneys' fees.").

227. See Alyeska Pipeline Serv. Co. v. Wilderness Soc'y, 421 U.S. 240, 245 (1975) (recognizing the "American rule"). See also Thomas D. Rowe, Jr., The Legal Theory of Attorney Fee Shifting: A Critical Overview, 1982 DuKE L.J. 651, 651 (1982).

228. For example, in civil rights litigation this has been termed the "private attorney general" situation. See La Raza Unida v. Volpe, 57 F.R.D. 94, 98 (N.D. Cal. 1972), affd, 488 F.2d 559 (9th Cir. 1973).

229. See supra Part III.A.

230. See supra Part III.A.2.a. 
bar associations are aware of these problems, there is more that could be done to encourage and educate attorneys to self-regulate this specific form of problematic behavior.

First, the ABA or state bar associations could issue formal ethics opinions stating that the Model Rules prohibit sending abusive cease-anddesist letters. This would help clarify the applicability of the rules to this practice and hopefully reduce the incidences of attorney-written, abusive cease-and-desist letters. Second, state and local bar associations should conduct educational programs for its members on the particular issues that arise when dealing with low-resourced targets of cease-and-desist letters in order to help with the problem of partisanship. Finally, local bar associations should provide enhanced outreach to low-resourced targets to specifically educate them on how to handle cease-and-desist letters, which could assist in overcoming their inability to information-gather and in overcoming their susceptibility to inducement.

\section{Formal Ethics Opinion Interpreting Model Rules of Professional Conduct to Prohibit Abusive Cease-and-Desist Letters}

The ABA Committee on Ethics and Professional Responsibility and state bar associations sometimes issue formal ethics opinions interpreting applicable ethical rules.231 These opinions range in topics, from interpreting the rules prohibiting sexual relations with clients to those allowing attorneys to communicate with clients through unencrypted email.232 State bar associations often address similar topics as the ABA. 233 Although these ethics opinions are not formally binding, they are quite influential.234

As discussed in Part III.A, Model Rules 3.1 and 4.4 do not explicitly

231. See, e.g., ABA Comm. on Ethics \& Prof'l Responsibility, Formal Op. 468 (2014) (interpreting MOdel Rules Of Prof'L CONDUCT r. 1.17 (2013)); Cal. State Bar Standing Comm. on Prof'l Responsibility \& Conduct, Formal Op. 12-0007 (2014) (interpreting CAL. RULES OF PROF'L CONDUCT r. 3-100, 3-700(B)(2) (2013)).

232. See ABA Comm. on Ethics \& Prof'l Responsibility, Formal Op. 92-364 (1992) (discussing sex with clients); ABA Comm. on Ethics \& Prof'l Responsibility, Formal Op. 99-413 (1999) (discussing protecting the confidentiality of unencrypted email).

233. For example, in 2006, the ABA released a Formal Opinion on when "puffing" is appropriate in negotiations, and the California State Bar Association released a similar formal opinion in 2014. See ABA Comm. on Ethics \& Profl Responsibility, Formal Op. 06-439 (2006); Cal. State Bar Standing Comm. on Prof'l Responsibility \& Conduct, Formal Op. 12-0007 (2014).

234. See Lawrence K. Hellman, When "Ethics Rules" Don't Mean What They Say: The Implications of Strained ABA Ethics Opinions, 10 GEO. J. LEGAL ETHICS 317, 325-26 (1996). 
prohibit legal rights enforcement through the use of abusive cease-and-desist letters. While there are formal ethics opinions that discuss related areas, the lack of a formal ethics opinion directly on the topic of abusive cease-anddesist letters leaves a gap in regulation. For example, ABA Formal Opinion 94-383, "Use of Threatened Disciplinary Complaint Against Opposing Counsel," interprets the Model Rules to prohibit attorneys from threatening to file disciplinary charges against an opposing counsel in order to coerce settlements.235 Where an attorney threatens to file a disciplinary charge, but has no actual intent to do so, this behavior is interpreted to violate Rule 4.1, which requires a lawyer to be truthful in dealings with others on a client's behalf.236 While this formal opinion appears to address the prohibition of abusive letters generally, it is directed specifically at the use of an unrelated disciplinary action to coerce settlement. Abusive cease-and-desist letters contain threats that are related to the legal violation claims alleged in the letter. A formal ethics opinion that clarified that Model Rules 3.1, 4.4, and 4.1 prohibited attorneys from sending abusive communications to adverse parties would assist in bringing awareness to this issue.

While attorneys are aware of their ethical obligations to not allege weak or unreasonable legal rights violations, many are likely unaware of the additional requirement to be non-abusive. 237 Unfortunately, it has become the norm in the legal profession to include abusive tactics and legalese to blanket cease-and-desist letters with a posturing air of seriousness or authority. 238 A formal ethics opinion unambiguously stating the "do's" and "don'ts" of cease-and-desist letters would clarify that the ethical obligations require attorneys to be non-coercive in private settlements. While this would help stem the incidences of abusive letters by changing the norms of the cease-and-desist letter process, problems associated with partisanship would still exist because attorneys would still be placed in situations where they are supposed to be advocating for one side, and therefore may not be objective judges of ethics.

235. See ABA Comm. on Ethics \& Prof'l Responsibility, Formal Op. 94-383 (1994).

236. Model Rules of Prof'L Conduct r. 4.1 (2013).

237. However, recognition of an ethical rule does not translate into full compliance. See Gallagher, supra note 8, at 496.

238. See The Mechanics of Ethical and Effective Cease and Desist Letters, SMITH \& Hopen, http://www.smithhopen.com/litigation_cease_and_desist_letter_strategies.aspx (last visited Feb. 20, 2015) (categorizing abusive cease-and-desist letters as the "furious demand," and describing them as very common in intellectual property litigation). 


\section{Member Educational Campaigns}

As a complement to issuing a formal ethics opinion, state and local bar associations should undertake campaigns of their members to educate them on the myriad of issues associated with abusive cease-and-desist letters. These issues would include the confluence of factors identified in this Article that create a coercive settlement process for low-resourced targets. These types of educational campaigns are not new since some state and local bar associations already conduct similar types of campaigns, such as those promoting "civility." 239 For example, the San Diego County Bar Association (SDGBA) has undertaken a "Campaign on Civility, Integrity, and Professionalism," in which it seeks to promote attorney civility inside and outside of the courtroom.240 To do so, it issued its own "Attorney Code of Conduct,"241 as well as "Guidelines for Effective and Professional Advocacy." "242 One of the SDCBA Guidelines states that "[i]n analyzing ethical dilemmas, do not simply ask yourself if it violates any law; also ask yourself if it is fair and if it is the right thing to do." 243 While this is an extremely helpful guideline, it is only useful insofar as attorneys view being abusive in cease-and-desist letters as an ethical dilemma. As previously discussed, partisanship aids in blinding attorneys from recognizing their ethical violations.244 Additional education is needed so attorneys can recognize ethical violations in the cease-and-desist letter process, which may include instruction on cognitive distortions. 245

239. See, e.g., Journal News, Statewide Civility Initiative Will Encourage Conversations, TENn. BAR Ass'N (Oct. 1, 2012), http://www.tba.org/journal/statewide-civility-initiative-will-encourageconversations; Joseph Paul Justice Burke III, Reap What You Sow: Bar Leaders as Cultivators of Civility, 38 BAR LEADER (Jan.-Feb. 2014), http://www.americanbar.org/publications/bar_leader/201314/january-february/reap_what_you_sow_bar_leaders_as_cultivators_civility.html.

240. SDCBA Campaign on Civility, Integrity, and Professionalism, SAN DIEGO CNTY. BAR ASS'N, https://www.sdcba.org/index.cfm?pg=Civility (last visited Mar. 15, 2015).

241. The SDCBA Attorney Code of Conduct, SAN Diego CNTY. BAR Ass'N, https://www.sdcba.org/index.cfm?pg=AttyCodeConduct (last visited Mar. 15, 2015).

242. San Diego County Bar Association Guidelines for Effective and Professional Advocacy, SAN DIEGO GNTY. BAR ASS'N, https://www.sdcba.org/SDCBA/docDownload/15452 (last visited Mar. 15, 2015).

243. Id.

244. See supra Part III.A.2.a.

245. See Perlman, supra note 158, at 37-38 (suggesting that cognitive bias awareness be included in legal education). 


\section{Outreach to Small Businesses and Individuals}

Finally, additional attention by state and local bar associations should be given to low-resourced targets of abusive cease-and-desist letters for two different reasons. First, access to legal resources could assist in overcoming an inability to information-gather, as well as lower the susceptibility to inducement. While many, if not all, state and local bar associations have pro bono programs and lawyer referral systems, these programs appear to be available only for indigent individuals facing personal legal issues.246 Lowresourced targets may face threats to their personal life, but also to their business. While there are a few resources addressing these problems, better outreach is needed. 247

A few bar associations, like the Massachusetts Bar Association, have programs like "Dial-a-Lawyer," which allows any Massachusetts resident to call and speak to a volunteer attorney about any legal problems or questions.248 The "Dial-a-Lawyer" service is offered every first Wednesday of the month for a two-hour period, and is intended to reach those in the community who could not otherwise access legal advice. ${ }^{249}$ Additional efforts like these are needed across the country, and additional publicity needs to be given to these types of programs so small businesses know that they do have access free or low-cost legal advice.

Second, outreach to low-resourced entities should also educate this population about the appropriate behavior of attorneys and disputants. Enforcement of the rules governing attorney conduct is suboptimal due in part to ignorance of recipients of abusive cease-and-desist letters. While a number of local bar associations have attempted to mitigate some of the unawareness through online reporting systems,250 more can be done to

246. See, e.g., Legal Resource Finder-Find Legal Aid, MassLegalSERvices, http://www.masslegalservices.org/findlegalaid (last visited Mar. 15, 2015) (listing broad categories covering personal legal issues for which it provides assistance).

247. Volunteer Lawyers for the Arts is one organization that assists artists and cultural organizations. See, e.g., Volunteer Lawyers for the Arts, ARTS \& BUS. COUNCIL OF GREATER BOS., http://www.artsandbusinesscouncil.org/programs/volunteer-lawyers-for-the-arts.html (last visited Mar. 15, 2015). In addition, law school clinics that focus on small business needs are a recently developed avenue of assistance for low-resourced targets. See, e.g., Intellectual Property Eै Entrepreneurship Clinic, SUFFOLK UNIV. LAW SCH., http://www.suffolk.edu/law /academics/clinics/21858.php (last visited Mar. 15, 2015); USC Small Business Clinic, USG GouLD SCH. OF LAW, http://lawweb.usc.edu/why/academics/clinics/sbc/ (last visited Mar. 15, 2015).

248. Dial-A-Lawyer Offers Free Legal Advice Each Month, MASS. BAR Ass'N, http://www.massbar.org/for-the-public/need-a-lawyer/dial-a-lawyer (last visited Mar. 15, 2015).

249. Id.

250. See, e.g., FAQS: How Do I File a Complaint Against an Attorney?, MASS. BAR Ass'N, 
educate low-resourced entities and the general public about ethical attorney behavior and methods of reporting unethical behavior. 251

\section{G. More Aggressive Action by the FTC and State Attorneys General}

While the two proposals above attempt to attack the problem of abusive letters from the sender side by altering the incentives to send an abusive letter, and from the target side by assisting in overcoming two characteristics creating a coercive settlement environment, the third characteristic - the inability to follow through with litigation - is not necessarily mitigated. One additional proposal to address this characteristic is to enlist the aid of the state attorneys general offices and the FTC. The state attorneys general and the FTC have attempted to utilize consumer protection law to stop abusive cease-and-desist letters from being sent to low-resourced targets. 252 However, currently, such actions have been limited to exceptional situations involving a large volume of letters and deceptive letter senders.253 Attributing to this limited applicability may be the fact that the typical abusive cease-and-desist letter does not neatly fit within the regulations of consumer protection law, particularly where the letter is not deceptive. ${ }^{254}$ However, in a statement before a House of Representatives hearing on a current anti-patent troll bill, a representative for the FTC stated that the Commission believed it had the authority to enforce in this area, and the FTC was defending itself in a lawsuit by MPHJ Technology challenging its authority. 255

Another reason for the lack of widespread enforcement efforts may be the state attorneys general offices and the FTC's lack of resources. As the enforcement agency for consumer protection laws, state attorneys general offices and the FTC enforce a range of different laws, and not just those pertaining to unfair and deceptive trade practices.256 With budget crunches

http://www.massbar.org/for-the-public/faqs\#13749 (last visited Mar. 15, 2015); Laweyer Regulation, CAL. STATE BAR, supra note 165.

251. See, e.g., What Can I Do If I Have a Problem with My Lawyer, Cal. State BaR, http://calbar.ca.gov/Public/Pamphlets/ProblemwithaLawyer.aspx (last visited Mar. 15, 2015) (providing additional information educating the public about ethical attorney behavior).

252. See supra Part III.D.

253. See id.

254. See id. Some policymakers believe that this area should be subject to FTC enforcement. See Baluch, supra note 190, at 17-20 (discussing the different methods that members of Congress presented attempting to allow the FTC to more directly regulate abusive demand letters).

255. See Statement of Lois Greisman, supra note 194.

256. See Enforcement, FeD. TRADE COMM'N, http://www.ftc.gov/enforcement (last visited 
at state attorneys general offices across the nation, an issue needs to be a top priority in order to allocate funding, otherwise only the most egregious cases will likely be investigated. 257

Despite resource constraints, the FTC or state attorneys general could alternatively promulgate rules to combat abusive cease-and-desist letters. For example, the FTC obtains its authority to promulgate rules regarding unfair or deceptive trade practices from the Federal Trade Commission Act.258 As part of this rule-making power, the FTC has promulgated specific rules relating to abusive practices, such as creditor letters, and requires specific disclosures to be made to consumers regarding loans.259 A similar identification of abusive cease-and-desist letters as an unfair business practice, and perhaps requiring disclosures, could be promulgated through its rule-making authority. While this would not increase the resources that the offices have to enforce their rules, and thereby not necessarily assist in overcoming the inability to follow through with litigation, it could provide a deterrent effect to potential senders of abusive letters.

\section{Griticisms of Policing Cease-and-Desist Letters}

Although the proposals in Part IV attempt to police abusive cease-anddesist letters, a number of potential downsides may detract from the urge to regulate this area of the law. Three main criticisms of such regulation are (1) the potential for encouraging litigiousness, (2) the potential for increasing the costs of enforcement for small businesses and individuals, and (3) over-

Mar. 15, 2015).

257. See, e.g., Timothy B. Wheeler, State Trying to Cope with Backlog of Pollution on Violation Cases, BALT. Sun (Nov. 29, 201 1), http://articles.baltimoresun.com/2011-11-29/features/bs-gr-enforce20111123_1_backlog-violations-enforcement ("And with the state's budget crunch, MDE has been unable to get funds for more positions, so the attorney general's office could not hire more lawyers to handle the jump in cases ...."); Pamela Prah, Texas Saves Big Money Through Effective Child Support Enforcement, PEw CHARITABle Trusts (Sept. 21, 2011), http://www.pewtrusts.org/en/researchand-analysis/blogs/stateline/2011/09/21/texas-saves-big-money-through-effective-childsupport-enforcement ("On top of the state budget crunch, federal stimulus dollars for child support have run out. Overall, the attorney general's office says it will have $\$ 110$ million less in federal and state money for child support enforcement over the next two years than in the previous biennium."); Christopher Wills, Illinois Attorney General Pushes Back on Budget, ST. J. REG. (Mar. 8, 2012), http://www.sj-r.com/article/20120308/News/303089888 ("[Illinois Attorney General] is pushing back against the governor's call for deeper budget cuts, saying her office's ability to generate money for tax payers is already being threatened by low pay and low morale that make it hard to retain her top lawyers.").

258. 15 U.S.G. $\$ 57 \mathrm{a}(\mathrm{a})(1)(2012)$.

259. See 16 C.F.R. § 444.3 (current through Mar. 12, 2015) (requiring lenders to inform cosigners about the nature of his or her liability). 
regulating private dispute resolution.

\section{A. Potentially Encouraging Litigiousness}

This Article acknowledges that implementing an anti-abusive threats law could encourage an additional level of litigiousness.260 By providing targets of abusive cease-and-desist letters with a private cause of action, some targets may decide to unreasonably or frivolously interpret "abuse." Additionally, some targets may unreasonably view any cease-and-desist letter as abusive. 261 While this is a valid concern, it could be overcome by tailoring the new law in such a way to discourage frivolous abusive threats actions. One way to do this could be through a two-way fee shifting provision. Thus, whichever party loses the suit bears the burden of the attorneys' fees for the other party. Such could deter the filing of frivolous complaints by adding a potential cost to the litigation.262 An example of such a mandatory two-way fee shifting provision is seen in California's anti-SLAPP law.263

Although there are reported cases where targets of cease-and-desist letters sue the sender, 264 there is currently no outcry over frivolous lawsuits. 265 In fact, in some jurisdictions, such as in the United Kingdom, the opposite is true - legal advisers feel curtailed to send demand letters due to the potential

260. This is a concern of the United Kingdom, which recently undertook a review of their "groundless threats" law. See generally U.K. LAW COMM’N, CONSUltation PAPER No. 212: Patents, Trade Marks and Design Rights: Groundless Threats (2013) [hereinafter U.K. LAW COMM'N: CONSUlTATION PAPER].

261. See U.K. Law Comm'N, Patents, Trade Marks and Design Rights: GROUNDLESS THREATS 77 (Apr. 2014), available at http://lawcommission.justice.gov.uk /docs/lc346_patents_groundless_threats.pdf [hereinafter U.K. LAW COMM'N: REPORT] ("The difference between 'mere notification' and a threat is in the eye of the receiver ....").

262. But see Susanne Di Pietro, Teresa W. Carns \& Pamela Kelley, Alaska Judicial

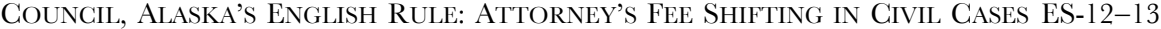
(Oct. 1995), available at http://www.ajc.state.ak.us/reports/atyfeeexec.pdf (noting that the effect of fee shifting provisions can be mixed and there is no empirical evidence to prove that it does discourage frivolous litigation); Douglas C. Rennie, Rule 82 \& Tort Reform: An Empirical Study of the Impact of Alaska's English Rule on Federal Civil Case Filings, 29 ALASKA L. REv. 1, 2-3 (2012).

263. CAL. GIV. PROC. CODE § 425.16(c) (West 2015) (“[A] prevailing defendant on a special motion to strike shall be entitled to recover his or her attorney's fees and costs. If the court finds that a special motion to strike is frivolous or is solely intended to cause unnecessary delay, the court shall award costs and reasonable attorney's fees to a plaintiff prevailing on the motion ....").

264. One recent example from Australia is Bell v. Steele, where the plaintiff (the target of the cease-and-desist letter) won and was awarded \$147,000. Mary Still \& Jessica Cowell, One Good Reason to Take Care Before Threatening Legal Action in Copyright Disputes, CLAYTON UTZ (Mar. 29, 2012), http://www.claytonutz.com/publications/edition/29_march_2012/20120329/one_good_reason _to_take_care_before_threatening_legal_action_in_copyright_disputes.page.

265. It is difficult to prove a negative, and there are no direct statistics on this. 
for a lawsuit, but do not complain about being overly sued.266 This evidence suggests that introducing an appropriately tailored, abusive threats action should not cause a drastic increase in litigation.

\section{B. Increasing Enforcement Costs for Small Businesses and Individuals}

Another serious concern with respect to the proposed abusive threats cause of action is that it could harm small businesses and individuals attempting to enforce their legal rights. If a small business or individual tries to enforce their legal rights by sending a cease-and-desist letter without the aid of an attorney, they could be subject to an abusive threats lawsuit. This criticism has merit and would force some small businesses and individuals to forgo enforcement altogether. ${ }^{267}$ The inability to enforce certain legal rights, such as intellectual property rights, is an argument that is used by some patent trolls as a benefit to having non-practicing entities.268 Patent trolls advocate that with an aggregation of patents and resources, the entity (not the small business or individual patent owner) can enforce rights that would otherwise be practically unenforceable. 269

However, this Article maintains that the current legal environment is such that small businesses and individuals already lack the ability to fully enforce their legal rights without additional assistance. 270 An example is the

266. See U.K. LAW COMM'N: REPORT, supra note 261, at 35 (reporting that some legal advisers may be reluctant to put their name to a letter).

267. Taken to the ultimate extreme, a lack of any enforcement by an intellectual property rights holder could mean a loss of the intellectual property right. See, e.g., 6 J. THOMAS MCCARTHY, MCGARTHY ON TRADEMARKS AND UNFAIR COMPETITION § 31:12 (4th ed. 2014) ("Laches is a good defense if plaintiff's long failure to exercise its legal rights has caused the defendant to rely to its detriment by building up a valuable business around its trademark."). While this is a rare scenario, it is an argument often used by those who would advocate against reform in this area.

268. See, e.g., Matt Levy, Three Myths About Intellectual Ventures, Patent Progress (Sept. 17, 2013), http://www.patentprogress.org/2013/09/17/three-myths-intellectual-ventures/ (reporting that it is a myth that Intellectual Ventures, a patent troll, helps small inventors).

269. See When Patents Attack, NPR (July 22, 2011), http://www.npr.org/blogs/money /2011/07/26/138576167/when-patents-attack (quoting Joe Chernesky, a vice-president at Intellectual Ventures) ("The neat thing about Chris is he had no idea how to get money for his patents. He had this great idea. These patents were immensely valuable because every technology company was adopting the technology. Yet he didn't know how to get paid. He eventually found Intellectual Ventures. So we bought those patents.”). But see Mike Masnick, This American Life Followup on Patents Reveals Intellectual Ventures is Even Slimier Than Previously Believed, TECHDIRT (June 3, 2013), https://www.techdirt.com/articles/20130603/11295023297/this-american-life-followuppatents-reveals-intellectual-ventures-is-even-slimier-than-previously-believed.shtml.

270. See Grinvald, supra note 15, at 654-63 (arguing that small businesses and individuals 
case involving Maureen Reddy, an individual inventor with a patent on a light shade design. In 2012 Reddy pitched her patented product design idea to Lowe's Home Improvement.271 Despite her pending patent, Lowe's subsequently began selling an extremely similar design.272 Reddy's circumstances were such that she would not have been able to enforce her patent without the free representation provided by Suffolk Law School's clinic. 273 Therefore, even though there is a chance that adding a cause of action for abusive threats could raise the cost of enforcement for small businesses and individuals, overall the practical impact would likely be low. For enforcement to be more accessible for this population, greater access to low-cost or free legal assistance is needed, regardless of an additional abusive threats action.

\section{Over-Regulating Private Dispute Resolution}

A more theoretical concern with any proposal to police abusive ceaseand-desist letters is that this is merely another unnecessary intrusion into the private dispute resolution process of private individuals. Contained within this broader distaste for additional regulation of private disputes is a valid concern that the proposed abusive threats action could stymie good faith attempts at negotiating private settlements with alleged infringers. ${ }^{274}$ Since one of the overarching goals of this Article's proposals is to encourage good faith attempts at discussion and negotiation between rights holders and targets, this concern is important.

The experiences of other countries are instructive in assessing any proposed regulations. The United Kingdom Law Commission's (the "Law Commission") study of threats actions discovered that intellectual property rights holders feel thwarted when inquiring about potential infringements due to a fear of being sued for groundless threats.275 Although in the United Kingdom groundless threats law is slightly different than the one proposed, the recent review by the Law Commission suggests that the groundless threats law should be reformed to include an explicit safe harbor provision

\footnotetext{
cannot and should not litigate trademark infringement claims).

271. David v. Goliath: Clinic Takes Early Victory Against Lowe's, supra note 117.

272. Id.

273. Id. (quoting Eve Brown, the clinic's director).

274. See U.K. LAw COMM'N: CONSUltation PAPER, supra note 260, at 91-109 (documenting various problems that detract from good faith negotiation attempts).

275. See U.K. LAW COMM'N: RePORT, supra note 261, at 77.
} 
for legitimate communications. ${ }^{276}$ This safe harbor is intended to allow for freer communications between an intellectual property rights holder and the alleged infringer. The elements of the communications protected by the United Kingdom's proposed safe harbor are those to (1) track down the source of infringement; (2) prevent an infringer from raising an innocent infringer defense; or (3) open negotiations for license terms.277 A similar explicit safe harbor could be written into the proposed anti-abusive threats law, with elements focusing on reasonability and whether the sender was attempting to open the lines of communication between the two parties.278 Although this Article does not advocate any particular elements for such safe harbor, elements could include a reasonable timeframe given to the target of the letter, and language to encourage the target to seek the advice of legal counsel to discuss the letter's claims.

\section{Conclusion}

The increase in sending abusive cease-and-desist letters as a means to enforce legal rights is a nationwide phenomenon affecting entities and individuals of all different sizes, and has implications on private dispute resolution processes. Although this is problematic overall, it is particularly disturbing when the targets of abusive letters are small businesses and individuals due to the coercive negotiation environment created. When lowresourced individuals or businesses enter into a settlement agreement with abusive letter senders, they are likely coerced due to their inability to information-gather, susceptibility to inducement, and an inability to finance the litigation. Therefore, such agreements should be declared void. However, due to the inability of this population to litigate, these coerced agreements would likely never be invalidated, and a situation of de facto enforceability of coerced agreements ensues. This Article proposes a number of different solutions to reduce the factors that create the coercive environment in the hopes of encouraging a good faith and more equalized settlement processes. While there are limitations and downsides to these proposals, particularly with respect to this Article's proposed anti-abusive threats law, these solutions should be considered as part of an overall conversation regarding reform in the area of the abusive over-enforcement of legal rights.

278. Safe harbors, when designed appropriately, can be effective vehicles for cutting down on unwanted litigation. See Eric Goldman, Designing Optimal Immunities and Safe Harbors, TECH. \& MKTG. LAW BLOG (Apr. 15, 2013), http://blog.ericgoldman.org/archives/2013/04 /designing_optim_1.htm.
} 